NBER WORKING PAPER SERIES

\title{
DIFFERENTIAL PRICING IN UNDERGRADUATE EDUCATION: EFFECTS ON DEGREE PRODUCTION BY FIELD
}

\author{
Kevin M. Stange \\ Working Paper 19183 \\ http://www.nber.org/papers/w19183 \\ NATIONAL BUREAU OF ECONOMIC RESEARCH \\ 1050 Massachusetts Avenue \\ Cambridge, MA 02138 \\ June 2013
}

I am incredibly grateful to Glen Nelson for sharing his data on differential tuition and for several very helpful discussions. Alfredo Sosa provided exceptional research assistance. Helpful comments were provided by numerous seminar participants at the University of Michigan, Columbia University Teachers College, and the Association for Education Finance and Policy Annual Meetings. Author can be contacted at kstange@umich.edu. All errors are my own. The views expressed herein are those of the author and do not necessarily reflect the views of the National Bureau of Economic Research.

NBER working papers are circulated for discussion and comment purposes. They have not been peerreviewed or been subject to the review by the NBER Board of Directors that accompanies official NBER publications.

(C) 2013 by Kevin M. Stange. All rights reserved. Short sections of text, not to exceed two paragraphs, may be quoted without explicit permission provided that full credit, including $\bigcirc$ notice, is given to the source. 
Differential Pricing in Undergraduate Education: Effects on Degree Production by Field Kevin M. Stange

NBER Working Paper No. 19183

June 2013

JEL No. I20,I22,I28,J24

\begin{abstract}
$\underline{\text { ABSTRACT }}$
In the face of declining state support, many universities have introduced differential pricing by undergraduate program as an alternative to across-the-board tuition increases. This practice aligns price more closely with instructional costs and students' ability to pay post-graduation. Exploiting the staggered adoption of these policies across universities, this paper finds that differential pricing does alter the allocation of students to majors, though heterogeneity across fields may suggest a greater supply response in particularly oversubscribed fields such as nursing. There is some evidence that student groups already underrepresented in certain fields are particularly affected by the new pricing policies. Price does appear to be a policy lever through which state governments can alter the field composition of the workforce they are training with the public higher education system.
\end{abstract}

Kevin M. Stange

Gerald R. Ford School of Public Policy

University of Michigan

5236 Weill Hall

735 South State Street

Ann Arbor, MI 48109

and NBER

kstange@umich.edu 


\section{Introduction}

The provision of higher education is one of the most important functions of state governments in the United States, accounting for \$170 billion of direct state spending in 2011 (NASBO, 2012). Historically states have attempted to provide their residents with access to high-quality postsecondary education by providing large subsidies directly to public institutions with few directives for how the money was used. Public institutions, in turn, charged all students a price well below cost, with very little price variation between in-state undergraduate students within institutions. $^{1}$

However, escalating tuition and tight state budgets have placed higher education institutions under recent scrutiny, as lawmakers debate what type of education government should be promoting and who should pay for it. One of the more high-profile proposals stemming from these debates is the recent effort by Florida Governor Rick Scott to nudge more students into majors in "strategic areas" like engineering and biotechnology by freezing tuition rates in these fields, while increasing rates for students in liberal arts (Alvarez, 2012). An alternative approach was taken at public universities in Texas following deregulation in 2004. Many institutions increased overall tuition rates and began charging higher rates for specific programs, at least partially in an attempt to improve the quality of these specific programs by generating additional resources (Kim and Stange, 2013). Michigan and Ohio recently followed the trend of many other states by making appropriations conditional on various measures of institutional performance, including the production of degrees in high-need fields (Jesse, 2012; Plant, 2012). At the national level, calls to increase the number of bachelor's degrees awarded in engineering and nursing (Executive Office of the President, 2012; Institute of Medicine, 2010)

\footnotetext{
${ }^{1}$ Public institutions do charge different prices to in-state and out-of-state students and lower prices to students that attend part-time, but other forms of price differentiation within institutions are less pronounced historically.
} 
motivated the SMART Grant program and various workforce provisions of the Affordable Care Act. ${ }^{2}$ In short, policy-makers at many levels are attempting to alter the mix of undergraduate degrees to achieve the greatest return on the public's substantial investment in higher education.

The efficacy of many of these efforts depends on the responses of students and institutions to changes in major-specific prices, a topic about which little is known. This question is the focus of this paper. The situations in Texas and Florida are not atypical, as institutions across the country are increasingly charging students higher prices for upper division coursework and for certain high-cost majors such as engineering, business, and nursing. This reverses the historical convention of universities charging all undergraduates the same price regardless of field. A recent survey found that forty-two percent of public doctoral institutions now charge differentially either by field or level, with field-based differentials much more common (Ehrenberg, 2012). Given the heightened scrutiny and financial pressure faced by institutions, differential pricing may very well become the new standard practice in undergraduate education, as it is in graduate education. Since differential pricing could induce both demand and supply responses, the combined effect on the sorting of students into majors is theoretically ambiguous and thus an important and unanswered empirical question.

In this paper, the effect of differential pricing is estimated using data on the mix of degrees awarded by 142 large public research universities from 1990 to 2010. Fifty of these universities adopted differential pricing for engineering, business, or nursing during this time period. These three fields are the most common targets for differential pricing and also account for a sizable share of all undergraduate students. Employing a difference-in-differences and event-study strategy, I compare changes in the share of degrees awarded in certain fields at these universities

\footnotetext{
${ }^{2}$ See Evans (2012) for a discussion of the recently discontinued SMART Grant program and Morgan (2010) for discussion of the nursing and other health workforce provisions in the Affordable Care Act.
} 
to changes at schools that did not alter their tuition policy during the same time period. Several different plausible control groups - colleges that adopt differential pricing at different times, colleges that considered adopting (but didn’t), non-adopters in the same region and selectivity category - are used to estimate the counterfactual time trend that adopters would have experienced had they not enacted price differentials. The event-study model finds no evidence that schools adopting differential pricing policies were trending differently than control schools prior to adoption.

The results indicate that differential pricing for engineering is associated with a statistically significant 1.1 percentage point decrease in the share of degrees awarded in engineering after three years (on a base of 14.7 percent). The analogous figure for business is an (imprecise) 0.8 percentage point decrease in the business share within three years (on a base of 19.5 percent). Differential pricing for nursing is actually associated with a 0.8 percentage point increase in the nursing share (on a base of 4.4 percent), though this is imprecise and not significantly different from zero. These patterns are robust across a number of specifications, covariate adjustments, different control groups, and samples. I also find that women and minorities have larger proportionate effects than male and white students. Using individual-level data, I find no evidence that additional institutional grant aid offsets the increased tuition for impacted majors. Since the effects I uncover combine both a demand and supply response, different responses across fields may reflect differences in demand parameters, that the supply response differs across fields, or that fields are in different initial equilibrium states. It is possible that additional revenue enables an expansion in the supply of over-subscribed nursing positions while the quality and capacity enhancement of engineering programs is not sufficient to overcome the price impact on demand. 
This paper provides the first evidence on the consequence of a new model for pricing in higher education, which has grown significantly and is likely to become the norm in the near future. Graduate training has long differentiated price based on instructional cost and students' willingness (or ability) to pay, but this has become widespread in undergraduate education only recently. Price does appear to be a policy lever through which state governments can alter the field composition of the workforce they are training with the public higher education system.

This paper proceeds as follows. The next section provides a brief background on differential pricing. A framework for interpreting the empirical results is presented in Section III. Previous literature is discussed in Section IV. Section V describes the data used in the analysis and the empirical strategy. Results and robustness are discussed in Section VI. Section VII concludes.

\section{Background on Differential Pricing}

Differential pricing by major has been advocated by economists and educational scholars periodically for quite some time. Proponents of differential pricing cite two primary rationales (Hoenack and Weiler, 1975, Siegfried and Round, 1997, Nelson 2008). First, differentials make the price students experience align more closely actual instructional costs, eliminating the implicit cross-subsidy across major fields that results from the conventional practice of charging similar prices. The cost of instruction differs tremendously between upper and lower division coursework and across programs even within institutions. For instance, recent analysis of cost data from four large state postsecondary systems (Florida, Illinois, New York-SUNY, and Ohio) indicated that upper division instruction costs approximately $40 \%$ more per credit hour than lower division instruction, and that upper-division engineering, physical science, and visual/performing art was approximately $40 \%$ more costly than the least costly majors (SHEEO, 
2010). In fact, an earlier but more extensive cost study found that more than three-fourths of the variance in instructional cost across institutions is explained by the disciplinary mix within an institution (U.S. Department of Education 2003). The consequence is that lower division students subsidize upper-division students and students in costly majors are subsidized by those in less expensive ones. Of course, institutions also benefit from the reputation and donations of graduating alumni, which may offset these cost differences at many of these schools.

Second, tuition differentials better align prices with students' ability to pay postgraduation. Lower division includes many students who eventually drop out, while students that have advanced to upper division are more likely to graduate and earn more. Engineering, science, and business majors tend to earn more and have higher returns than education and humanities majors, even after controlling for differential selection of major by ability (Arcidiacono 2004). Higher earnings upon graduation mean that graduates with these degrees are thus in a better position to finance higher tuition fees with loans. Again, non-differentiated pricing implicitly creates cross-subsidization that runs counter to differences in post-schooling earnings and ability to pay. In addition to being regressive, this pattern of cross-subsidization is highly unusual; profit-maximizing firms in other markets are predicted to charge based on marginal cost and willingness to pay.

Some opponents of the changes worry that tuition differentials will adversely affect student choice, particularly for low-income students (Nelson 2008). A related concern is that differential tuition practices will make it even more difficult to increase participation in STEM fields and in health professions such as nursing, as some of these fields are often the target of tuition differentials. Others worry that differential tuition will discourage student exploration 
(Redden, 2007), undermining the liberal arts goals of institutions and resulting in worse matches between students and majors or occupations.

A few large public universities, such as the University of Illinois and the University of Michigan, have charged more for upper division coursework and for high-cost majors for quite some time (Yanikoski and Wilson, 1984). However, many more universities have recently implemented explicit differential prices by level and program as an alternative to across-theboard tuition and fee increases. In a broad survey of 165 public research universities, Nelson (2008) found that $45 \%$ of schools have at least one undergraduate program with differential tuition or fees in 2008, with most implementing them in the past decade. This share was up to 57\% by 2011 (Reed 2011). Many more, such as the University of California System, have

recently considered and rejected such a scheme (Gordon 2009, University of California Office of the President 2009) or have commissioned studies of pricing practices at other institutions as a possible first step to considering such schemes (University of Washington Office of Planning and Budgeting 2011). Differential pricing by level, independent of major program, is rarer, but still present at some institutions (Simone 2010, Ehrenberg, 2012). A recent survey found a continuation of this trend: $42 \%$ of all public doctoral institutions had some form of tuition differential in 2010-2011, as did many public masters and bachelors-level public institutions (18\% and 30\%, respectively) (Ehrenberg, 2012). The enactment of these practices has grown steadily since the mid-1990s with no sign of slowing down (Cornell Higher Education Research Institute, 2012).

\section{Possible Demand and Supply Channels}

The introduction of differential pricing by program could induce both a demand and supply response, so the combined effect on the sorting of students into majors is theoretically 
ambiguous. This section discusses the possible demand and supply channels to help interpret the reduced form effects uncovered in the empirical analysis. Throughout I assume that programspecific price at each institution, $P$, is set externally (e.g., by a Board of Trusties or legislature), so that individual departments and students act as price-takers and $P$ does not necessarily equate supply and demand.

On the demand side, individuals weigh the long-term expected benefits of studying a particular program against the short-term costs of doing so, as is typical in the human capital framework (Becker 1964). First suppose that supply is perfectly elastic. Individuals are thus free to choose the major for which the difference between expected benefit and cost is the greatest. Denote the net value that individual $i$ receives from receiving a degree in major $k$ at university $j$ to be $V_{i j k}=\beta_{1} P_{j k}+\beta_{2}$ Earnings $_{i}\left(Q_{j k}\right)+\beta_{3}$ Effort $_{i j k}+\delta_{j k}+\varepsilon_{i j k}$. The most salient benefit is the financial return, Earnings $i\left(Q_{j k}\right)$, which is a function of the quality of major $k$ at university $j$, where quality includes such things as class size, faculty prestige, and classroom technology. Benefits also include the non-financial aspects of careers associated with each major $\left(\delta_{j k}\right)$ or the consumption value during college. In most previous analysis of major choice, costs consist of the individual-specific non-financial effort costs (Effort $\left.{ }_{i j k}\right)$ stemming from the difficulty of completing each major. For instance, large differences in effort cost and study requirements exist between majors (Babcock and Marks 2011, Stinebrickner and Stinebrickner 2008). ${ }^{3}$ A differential tuition policy creates financial cost differences by program, $P_{j k}$, which may also

\footnotetext{
${ }^{3}$ Differences in required study time between majors could also be thought of as differences in the opportunity cost of time not available for work, given that many students combine work and schooling.
} 
influence demand. Under typical assumptions ${ }^{4}$, the marginal effect of an increase in price on the share of students choosing major $k$ at school $j$ is:

$$
\frac{d \text { Share }_{j k}}{d P_{j k}}=\left(\beta_{1}+\beta_{2} \frac{d \text { Earning }_{j k}}{d Q_{j k}} \frac{d Q_{j k}}{d \text { Price }_{j k}}\right)\left(\text { Share }_{j k}\right)\left(1-\text { Share }_{j k}\right)
$$

$\beta_{1}$ reflects the pure price effect, which is likely negative since higher prices should discourage students from entering impacted fields, holding all else constant.

However, price changes can also induce at least two supply responses which would alter students' major decisions. First, programs could use some of the additional revenue to improve quality $\left(\frac{d Q_{j k}}{d \text { rice }_{j k}}>0\right)$. If students value earnings $\left(\beta_{2}>0\right)$ and there are positive returns to major quality $\left(\frac{d \text { Earning }_{j k}}{d Q_{j k}}>0\right)$, then demand for major $k$ will reflect both a price and quality response, which are likely to be opposite signed. If the quality improvement is substantial, demand for a given program could actually increase when its price is raised. The key mediator is how much colleges reinvest additional revenue to improve the quality of impacted majors. ${ }^{5}$

Expanded capacity is a second supply response. Now suppose that department-level capacity is not perfectly elastic, but rather upward-sloping with price. Higher prices may enable units to teach more students without altering program quality (e.g. class size) by offering more course sections and hiring more faculty. If the initial price (set externally) is too low, demand will exceed supply creating capacity constraints and individual programs will ration slots with

\footnotetext{
${ }^{4}$ If unobserved determinants of demand for major $k\left(\varepsilon_{i j k}\right)$ are assumed to be i.i.d. with a type 1 extreme value distribution and individual heterogeneity of returns and effort cost is ignored, then major choice probabilities take the conditional logit form with the marginal effect given above.

${ }^{5}$ This discussion simplifies things by assuming that the effort costs and non-financial benefits of a given major are not altered when its price increases.
} 
non-price mechanisms (e.g. waiting lists, GPA cut-offs, separate application processes). In this case, an increase in price will enable a department to expand capacity, which could increase equilibrium quantity. If a department initially has excess supply (more slots available than students demand at the externally-set initial price), then demand effects will dominate and equilibrium quantity will decline as price increases (assuming no quality response).

To summarize, demand theory is unambiguous in predicting that differential pricing should discourage students from entering the impacted fields, holding all else constant. However, if impacted programs use the additional revenue to improve quality, the net effect on demand will be ambiguous since quality improvements will increase demand. Furthermore, if the equilibrium at initial prices is one of over-demand (a shortage of available seats), then higher prices may permit oversubscribed departments to expand supply and increase the total number of students. Thus, we may expect to see a range of effects across majors and institutions, depending on the major-specific elasticity of demand, the extent to which additional revenue is used to improve instructional quality, the elasticity of supply, and the nature of the equilibrium point at initial prices. The average combined effect of all these mechanisms across all institutions is thus an empirical question. While the data do not permit the separate identification of these various channels, it is important to keep in mind that the reduced form effects I estimate are a combination of responses by students (demand) and institutions (supply). This may be, however, the effect most relevant to policy-makers who have the ability to set prices, but do not directly control what individual departments do with any additional revenue.

\section{IV.Previous Literature}

There is a large body of evidence showing that students' enrollment, persistence, and college choices are influenced by net college price. A consensus estimate is that a $\$ 1,000$ change in 
college price (1990 dollars) is associated with an approximately 3-5 percentage point difference in enrollment rates (Kane 2006). Evidence on the effect of college price on persistence and degree completion is rarer, but most studies suggest that persistence and completion are modestly responsive to prices for at least some groups (Bettinger 2004, Turner 2004, Dynarski 2008, DesJardins and McCall 2010, Goldrick-Rab et al 2011). Price also appears to be a strong predictor of the specific college students choose to attend (Long, 2004, Jacob McCall and Stange, 2013). All of this work exploits variation that affects prices of all majors simultaneously, so it sheds little light on the independent price effects across majors.

Previous research on the determinants of major choice has focused on expected earnings, student tastes or preferences, and student ability. Berger (1988) finds that students respond to predicted lifetime earnings across majors, rather than starting salaries, consistent with a standard economic life-cycle model. Montmarquet, Cannings, Mahseredjian (2002) extend this approach by including uncertainty about successful completion for each major. Arcidiacono (2004) estimates a dynamic structural model to control for selection into major and finds that student ability, preferences, and earnings all impact student choice of major. Exploiting differences in major-specific returns over the business cycle to eliminate selection bias, Beffy, Fougere, and Maurel (2011) find that the elasticity of major choice to expected earnings is significant, but low. They conclude that nonpecuniary factors are a primary determinant of major choices. ${ }^{6}$ Griffith (2010) finds that academic background, grade performance, and the educational focus of the institution explain a great deal of the higher exit rate of women and minorities from STEM fields.

\footnotetext{
${ }^{6}$ Very recently, researchers have begun to collect subjective expectations of earnings in each major in an attempt to isolate the effect of earnings expectations while relying on fewer assumptions about expectations (Arcidiacono, Hotz, and Kang 2011; Stinebrickner and Stinebrickner 2011; Wiswall and Zafar (2011). These papers all conclude that future earnings are an important consideration in students' major choice, though preferences and ability/background may be even more important.
} 
There has been almost no research on how major-specific prices affect students' major choice. One exception is a recent working paper by Evans (2012), who finds that eligibility for the National SMART Grant had little impact on students' likelihood of pursing a STEM major at public institutions in Ohio. Given the stringent eligibility requirements, low program participation, and specific setting of the study, these findings may not generalize to other forms of major-specific pricing. Furthermore, students' responses to earnings differences by major (for which there is evidence) may provide a poor guide to the likely effects of differential tuition. Students may weigh short-term and long-term financial considerations differently (Rothstein and Rouse, 2011), so price and earnings responses may be very different. I add to this literature by explicitly estimating the price response of major choice for a broad set of institutions using variation in their normal pricing practices, rather than through a specialized program. ${ }^{7}$

Evidence on the response of institutions to price (or resources more generally) is also limited, though the research that does exist has found that institutions reallocate resources when faced with changes in their budgets and that these reallocations have real impacts on students. For instance, Brown et al (2010) find that negative endowment shocks lead universities to reduce hiring (or accelerate the firing) of both faculty and support personnel (but not university administrators), but positive endowment shocks have no effect on these measures of real resources. Using changes in per-student funding arising from exogenous variation in cohort size across states over time, Bound and Turner (2007) conclude that funding for public universities has a large impact on both the quantity and the quality of college graduates because supply is far from perfectly elastic. A reduction in per-student state appropriations thus reduces collegiate

\footnotetext{
${ }^{7}$ Hoenack and Weiler (1975) and Berg and Hoenack (1987) discuss the implementation of cost-related tuition (an earlier name for "differential tuition") at the University of Minnesota and also present simulation results of the likely consequences. Neither of these papers directly assesses the impact of the policy, however. Hoenack and Weiler (1975) simulate major-specific price responses using the enrollment response to distance to approximate the enrollment response to differential tuition.
} 
attainment and the production of college-educated workers, though which mediating factors (reduced quality of instruction, fewer support services, less generous institutional aid) explain this relationship is not assessed. In one of the few studies that examined resource allocation within institutions, Johnson and Turner (2009) find that faculty salary differences across fields do correlate with student-faculty ratios, suggesting that economic factors (such as price) could cause institutions to reallocate instructional resources such as faculty. I am not aware of any evidence on the reallocation of resources across departments within institutions in response to greater revenue generated by specific departments. Though if institution-level evidence is any guide, we'd expect departments to increase both program quality and quantity (number of students) in response to differential pricing.

\section{Empirical Implementation}

\section{A. Data and sample}

Information on differential tuition prices by undergraduate major or program is not readily available from any standard data source. The most common source for tuition information, the Integrated Postsecondary Education Data System (IPEDS), only publishes differentials by instate status. ${ }^{8}$ I have obtained data on tuition differentials by program compiled by Nelson (2008). This data contains the incremental tuition or fees charged to different majors above base tuition (in percentage terms) for the 2007-2008 academic year at 161 public research universities. ${ }^{9}$ Seventy-four of these institutions had differential tuition for at least one program in 2007-2008. The data also contains information on the year of differential enactment and which schools

\footnotetext{
${ }^{8}$ IPEDS does currently collect program-specific tuition prices for some institutions, but these are vocationaloriented institutions and programs, not bachelors-granting undergraduate institutions. IPEDS did collect differential information for a few select years in the 1980s, but the reliability and completeness of this information is not clear.

${ }^{9}$ These were the 165 public research intensive and extensive institutions defined by 2000 Carnegie Classification categories 15 and 16. I exclude UCSF, CUNY-Graduate, U Maryland-Baltimore, and U Puerto Rico which had specialized undergraduate programs.
} 
considered (but did not implement) differential pricing. Of the 161 institutions, the precise timing of differential adoption was unavailable for 19 institutions, so my analysis focuses on the 142 remaining institutions (55 that adopted differential pricing for at least one program). My analysis focuses on the 50 institutions that had implemented differentials for engineering, business, and nursing majors as of the 2007/2008 academic year. These three fields are the most common fields in which differentials were enacted that also affect a sizable number of students. Though differentials for architecture and fine arts are also common, these impact a very small number of students and are ignored in my analysis. Table A1 in the appendix list the schools that adopted differential tuition policies for these three majors, along with the magnitude and timing of adoption. One limitation of the data is that the timing of field-specific differentials was not obtained, so I have assumed that differentials for all majors at a school were adopted at the same time. If schools enacted differentials for different fields during different years, then the timing may be misclassified, creating attenuation bias in my estimates.

The primary outcome I examine is the share of undergraduate degrees awarded by field, which is assessed using the IPEDS Degrees and Certificates Conferred (Completions) module. ${ }^{10}$ The raw data includes the number of students who complete a postsecondary program by Classification of Instructional Programs (CIP) code and level by sex and race. From this data I calculate the fraction of bachelor's degrees awarded in engineering, business, and nursing for each institution in each year from 1990 to 2008 overall and by sex and race. The full dataset thus contains 2698 observations (142 institutions X 19 years), though several specifications restrict this sample in different ways. Most importantly, many specifications restrict the sample to include only four years before and after the implementation of differential pricing for those

\footnotetext{
${ }^{10}$ I also estimate models with the logarithm of the number of degrees awarded in each field as the outcome variable and the results are qualitatively and qualitatively similar.
} 
institutions that adopt such policies so that baseline major shares for these institutions are estimated with observations close to the time of adoption. The resulting sample size is smaller (2,304 for Engineering, 2,234 for Business, and 2,489 for Nursing). This outcome data was supplemented with year-specific freshmen enrollment, tuition (in-state and out-of-state differential), resources (full-time faculty, state appropriations, and spending per FTE), and student attributes (\% full-time, \% in-state, Pell grant amount per FTE). Institutions are grouped into three selectivity categories, using the Barron's taxonomy (most or highly competitive, very competitive, competitive or less competitive).

Table 1 presents summary statistics of my analysis sample. Institutions that adopt differential pricing tend to be slightly larger and better resourced and are more likely to be in the "very competitive" category. Across all schools and years, business majors represent $18 \%$ of the sample, engineering $8 \%$, and nursing $3 \%$. Though the fraction of students choosing nursing is comparable across the three groups, institutions with differentials tend to have more engineering and business majors than colleges without differentials. Given these apparent differences between institutions with and without differentials, it will be important to control for observed (and unobserved) differences between colleges that may correlate with both major choice and the adoption of differential pricing.

To analyze how differential pricing affects the composition and financial aid of students in impacted fields, I also analyze individual-level data from the 1996, 2000, 2004, and 2008 waves of the National Postsecondary Student Aid Study (NPSAS). ${ }^{11}$ My NPSAS analysis sample consists of undergraduate students who attended one of these 142 universities, excluding

\footnotetext{
${ }^{11}$ An earlier version of this paper also used the NPSAS to assess major choice, but estimates from this analysis (which found no statistically significant effects of differential pricing) were extremely imprecise and thus abandoned in favor of using the IPEDS completions data. Using IPEDS completions data generates confidence intervals that are three to five times narrower and also permits the testing for pre-treatment balance using an event-study approach.
} 
students attending multiple institutions during the survey year, a few whose undergraduate level is missing, and any students whose major field is either missing or undecided/undeclared. I also restrict attention to full-time, full-year students so that financial aid differences do not reflect enrollment intensity. Across all four years, the NPSAS student sample contains approximately 18,000 students attending one of 141 universities. $^{12}$

\section{B. Identification strategy}

Institutions adopted differential pricing for these programs at different times throughout the past two decades. Using this staggered adoption, my basic empirical strategy is to compare changes in major shares at universities that have recently adopted differential tuition pricing to changes at universities that did not alter their tuition policy during the same time period. To implement this difference-in-differences strategy, I estimate regressions of the form:

$$
\text { EngShare }_{j t}=\beta \text { EngDiff }_{j t}+\alpha X_{i t}+\delta_{t}+\lambda_{j}+\varepsilon_{j t}
$$

In this specification, EngShare is the fraction of degrees awarded in engineering at university $j$ during year $t$. EngDiff is an indicator for whether $j$ charges differential tuition for engineering during year $t, X$ is a vector of time-varying institutional controls, $\delta$ is a set of year fixed effects, $\lambda$ is a full set of school fixed effects, and $\varepsilon$ is an error term. Aggregate time trends in major choice across all institutions (e.g. changes in the popularity of the business major) are accounted for by year fixed effects. School fixed effects control for average differences in field prevalence across institutions that may be related to the adoption of differential tuition policies. Time-varying school characteristics control for any changes in student population or school resources at the institution-level that may correlate with adoption of differential tuition. This specification is

\footnotetext{
${ }^{12}$ One of my 142 analysis institutions do not appear in the NPSAS. I have rounded the number of students to the nearest five hundred. Missing information on SAT score reduces this sample to 12,000 for analysis that relies on non-missing SAT scores. Using a balanced sample of institutions that appear in all waves of the NPSAS generates qualitatively similar estimates.
} 
conceptually equivalent to estimating a separate difference-in-differences model for each school that implemented differential tuition, then pooling these school-specific estimates. The coefficient of interest $(\beta)$ is the change in the change in share of degrees granted in engineering following the adoption of differential pricing for engineering. I estimate (1) separately for the three majors that have differential tuition most frequently - engineering, business, and nursing and that also represent a sizeable share of all college students. Standard errors are clustered by institution, to address the possibility that errors within schools are not independent.

The simple difference-in-differences specification assumes that outcomes for treatment and control schools would trend similarly in the absence of treatment. While inherently not testable, the panel data does allow one to test whether treatment and control schools were trending similarly in the years leading up to the adoption of differential pricing by the former. To do so, I estimate an event-study specification:

$$
\text { EngShare }_{j t}=\sum_{k=-3}^{k=4^{+}} \beta^{k} \text { StartEngDiff }_{j t+k}+\alpha X_{i t}+\delta_{t}+\lambda_{j}+\varepsilon_{j t}
$$

In the event study specification, StartEngDiff ${ }_{j k}$ indicates that institution $j$ adopted differential pricing for engineering $k$ years before year $t$. The parameter $\beta^{k}$ is the change in share of degrees granted in engineering $k$ years after the adoption of differential pricing relative to the omitted category ( $k=-4$ or earlier). For instance, $\beta^{3}$ is the change in share 3 years before adoption, $\beta^{0}$ is the share change in the year of adoption and $\beta^{4+}$ is the share change 4 or more years after adoption (all relative to four or more years before adoption). A suggestive test of the common trends assumption is that all the pre-treatment coefficeints are equal to zero. Another limitation of the simple difference-in-differences specification is that a new pricing policy may take a few years before affecting degree production, but it is not obvious how quickly this will happen. The 
event study specification has the additional benefit of quantifying how quickly policy effects develop.

Since major-specific price differentials are not experimentally assigned, there are several threats to identification that confound estimates of $\beta$. First, lifetime earnings differences across majors and unobserved student preferences for majors (or the jobs that certain majors lead to) cannot be directly entered as time-varying controls. If differential tuition is implemented for specific majors precisely when they become more desirable or lucrative at specific schools, $\beta$ will suffer from omitted variable bias. It thus may appear that students actually prefer to pay higher prices. To address this, some specifications compare schools within the same region or state and only include schools that considered (but did not implement) differential tuition as controls. Presumably demand for impacted majors was sufficiently high at these latter institutions to warrant a formal consideration of differential tuition. Region- and state-specific time trends control for any time-varying determinants of major share that are common to all institutions in the same geographic area, such as labor market conditions or K-12 preparation. For instance, the relative desirability of majoring in engineering at University of Oregon (no differential tuition for engineering) will serve as a counterfactual for the relative desirability of majoring in engineering at Oregon State and Portland State Universities (both enacted differential tuition for engineering in 1994) in each year. Since the models also control for institution fixed effects, any time-invariant differences across institutions will not confound estimates. Another strategy for addressing this concern is to test for pre-treatment trend differences between schools that do and do not adopt differential pricing. A lack of trend differences between adopting and non-adopting universities immediately before treatment occurs would also suggest policy adoption is not correlated with unobserved factors. Given the many 
political and legislative hurdles to adopting differential pricing, it is unlikely that institutions are able to control policy adoption with yearly precision.

Another possible confounder is financial aid. The vast majority of financial aid is based on need or general merit and is independent of program of study, so will not bias estimates of $\beta$. The only Federal financial aid program that specifically considers major is the SMART Grant, which provided large grants to Pell upperclassmen majoring in STEM fields or a critical foreign language from 2006 to 2010. Since this program was available to students at all institutions, regardless of differential pricing, its existence should not bias my estimates. However, it is possible that institutions may re-direct some of the additional revenue collected from differential tuition to financial aid for students in affected majors. I explicitly examine whether schools with differential tuition provide more institutional aid to students in affected majors conditional on merit and income.

Finally, I cannot rule out the possibility that institutions happen to implement other policies coincident with differential tuition. For instance, if differential tuition accompanied changes in the entry requirements for different majors or outreach by impacted departments, then my estimates will confound the pricing effect with these other policies as well. It should be reiterated that my estimates may combine a demand price response, a quality response, and changes in supply resulting from major-specific price differentials. Separately distinguishing demand and supply would require a different setting in which price was altered for only one side of the market in isolation.

\section{Results}

\section{A. “Case-study" Evidence}


I first document how the major share changes following each school's adoption of differential tuition. For each university that implemented differential pricing for engineering, business, or nursing between 1990 and 2008, I calculate the change in the fraction in each major following the policy change. The left panel of Figure 1 plots the distribution of these school-specific changes for the three majors. While there is substantial heterogeneity in schools' experience following the introduction of differential pricing, the majority of schools experienced a decrease in the fraction of students majoring in engineering and business. In contrast, a majority of schools experienced an increase in the fraction of students majoring in nursing when differential pricing for nursing was introduced. Since many things could be determining time trends in major choice at individual colleges and also be correlated with differential pricing, one should not necessarily interpret these raw estimates as causal effects. For instance, changes in the demand for certain fields within states that happen to correlate with changes in pricing policy may cause the simple change over time to not equal the causal effect of differential pricing on major share. The right column of Figure 1 plots the distribution of these school-specific changes after controlling for major-specific time trends using colleges in the same region and Barron's selectivity group as controls. ${ }^{13}$ This method controls for any time trends in the popularity of certain majors within regions and selectivity category. Though the distribution of estimates changes somewhat, the original pattern remains. This general pattern -negative effects of differential pricing on the fraction of degrees awarded in engineering or business and positive or

\footnotetext{
${ }^{13}$ The histograms plot the distribution of treatment effects estimated by school-specific difference-in-differences models. For each college that enacted differential tuition, I estimate a separate regression of MAJORSHARE $\mathrm{t}_{\mathrm{tj}}$ on $\operatorname{DIFF}_{\mathrm{tj}}\left(=1\right.$ if the college had differential tuition during year $\mathrm{t}$ ), $\operatorname{SWITCHER}_{\mathrm{j}}$ (a dummy for the college under study) and year dummies on a sample that includes the SWITCHER college and any other control colleges in the same census division and Barron's category (most/highly competitive, very competitive, competitive/less/noncompetitive). The histograms plot the distribution of estimated coefficients on DIFF $_{\mathrm{t} j}$.
} 
minimal effects on the fraction awarded in nursing - persists throughout a number of different identification strategies and robustness checks.

\section{B. Main Results}

Figure 2 presents estimates of the event study model separately by field using the restricted (+/- 4 year window) sample. ${ }^{14}$ The figure plots the point estimates and $95 \%$ confidence interval for the $\beta^{k}$ coefficients in equation (2). Consistent with the assumption that differential pricing was not implemented when these three majors were trending differently at treatment and control schools, the point estimates on the pre-treatment years are close to zero and insignificant. This finding gives some credibility to the key difference-in-differences assumption that treatment and control schools would have trended similarly if not for the adoption of differential pricing. However, the share of degrees awarded in engineering or businesses eventually drops following the enactment of differential pricing, while the nursing share increases. These event-study estimates also suggest that any treatment effects may take 3 to 4 years to emerge, as the point estimates experience their most notable change three years after differential pricing was enacted. To gain precision and to facilitate the comparison of many specifications, my preferred specification is a difference-in-differences model that permits separate effects for the immediate $(0,1$, and 2 years after the policy was enacted) and medium-run ( 3 and 4 years after) time periods. Table 2 presents these difference-in-differences results.

Columns (1), (5), and (9) present the raw correlation between differential tuition policies and major share. University-year observations in which differentials are in place for engineering and nursing are coincident with greater number of degrees awarded in these majors. The raw correlation for business majors is small, negative and insignificant. This raw correlation may

\footnotetext{
${ }^{14}$ Event-study estimates using the full balanced panel (not restricted to 8 year window around policy adoption) are qualitatively very similar, though larger in magnitude.
} 
overstate the positive effect of tuition differentials (or, rather, understate the negative effect) if differentials are implemented by universities whose students are predisposed to choose impacted majors, as a simple revenue-maximization goal would suggest universities should do. For instance, students with high SAT math scores are more likely to major in engineering and business and thus colleges with high SAT students may be more likely to implement tuition differentials. To address some of these concerns, columns (2), (6), and (10) control for year and university fixed effects. In these models, the effect of differential pricing on major share is identified by changes in major share within universities following the introduction of price differentials, relative to the time path of major share predicted by other (non-treatment) colleges. In all three cases, the point estimate becomes more negative and, in the case of engineering, becomes statistically significant. Specifications (3), (7), and (11) separate the post-treatment observations into two periods ( 0 to 2 years after adoption vs. $3+$ years). Consistent with the event-study estimates, the effect of differential pricing on the major shares are larger three years after enactment than immediately following. The final specifications restrict the analysis sample to include observations for treatment schools only within an eight-year window around the year differential pricing was enacted. Thus observations far from the time of the policy change are not used to identify the pre- or post-period school averages used to calculate the treatment effects. This restriction has the effect of diminishing the estimated effect for engineering and business share. This final (preferred) specification indicates that differential pricing for engineering is associated with a statistically significant 1.1 percentage point decrease in the share of degrees awarded in engineering within three years (on a base of 14.7 percent). The analogous figure for business is an (imprecise) 0.8 percentage point decrease in the business share within three years (on a base of 19.5 percent). Differential pricing for nursing is actually associated with a 0.8 
percentage point increase in the nursing share (on a base of 4.4 percent), though this is imprecise and not significantly different from zero. The 95\% confidence interval permits me to rule out negative effects larger than 0.37 percentage points. ${ }^{15}$

Given the magnitude of the price increase associated with these policies (increase in price of engineering by $14.5 \%$, business by $13.7 \%$ and nursing by $18.9 \%$.), these represent fairly large elasticities. For engineering and business, the implied elasticities are positive 0.51 and 0.30 , respectively. For nursing, the elasticity is positive and almost unity (elasticity $=1.0){ }^{16}$

\section{Robustness of Main Results}

The key untestable assumption of the difference-in-differences approach is that the time path for the outcome experienced by control schools provides a valid counterfactual for the time path of treatment schools in absence of the treatment. That is, the time trend in fraction of students graduating with a degree in engineering at schools that did not adopt differential tuition is what adopters would have experienced had they not implemented differential pricing. Given the centrality of this counterfactual time path to the validity of difference-in-differences estimates, the choice of control group is critical. My base model uses all non-adopters to form the control group, both schools that had differential tuition policies in place throughout the time period and those that never implemented one. Table 3 examines the robustness of the main findings to the choice of control group used to estimate the counterfactual time trends. The first column reports the base model, taken from columns (4), (8), and (12) from Table 2.

\footnotetext{
${ }^{15}$ Table A2 in the Appendix repeats this analysis using the logarithm of number of degrees granted as the outcome (rather than the share), both with and without controlling for the log of total number of degrees (in any field). The implied proportionate change in the share of degrees awarded in each field is similar with this specification. The log specifications (not controlling for total degrees awarded) also suggest that differential pricing is associated with an absolute decline in number of degrees awarded in engineering, not just as a share of the total.

${ }^{16}$ I find no correlation between institution-specific treatment effect size and the differential amount in 2008, as depicted in Appendix Figure A1. This suggests that size of the differential is less important than whether one is present. This result should be interpreted with caution, however, since differential amount is only available in a single year, which may not reflect the amount at the time it was introduced.
} 
Column (2) controls for observable time-varying differences in prices, resources, and student characteristics between treatment and controls that may happen to correlate with both degree mix and the adoption of differential pricing (time-invariant differences are absorbed by the school fixed effects). These controls leave the baseline estimates virtually identical. Column (3) includes controls for the simultaneous adoption of differential pricing in related fields. ${ }^{17}$ The presence of differentials for other (related) fields is relatively uncommon and has no impact on the point estimates. Column (4) controls for the simultaneous adoption of price differentials for the other two fields. Though magnitudes change modestly, the qualitative relationship is unchanged.

Columns (5) to (7) alter the control group by restricting the sample to students only attending schools that either adopted differential tuition during the analysis period or that are arguably more similar to adopters than a typical non-adopter school. These control groups include schools that have adopted some form of differential by 2007/8 in any field (column (5)), only universities that adopted a differential in the given major (6), and the 16 schools that considered (but did not adopt) tuition differentials in any field (7). The main qualitative results are generally robust to these various control groups, though the magnitudes of the point estimates does change somewhat. In (5) and (7), engineering differentials are associated with a 1.1 percentage point drop in the engineering share after three years. Specification (6) is the only anomaly, with a much smaller, but negative, and insignificant coefficient for engineering. It should be noted that this specification has a substantially smaller sample size than the others so I

\footnotetext{
${ }^{17}$ I include controls for differential pricing for architecture, computer science, or physical science when examining engineering share, liberal arts when examining business share, and other health professions and physical therapy when studying nursing share.
} 
cannot reject that coefficients are different. ${ }^{18}$ The coefficients for business and nursing change only slightly, remaining negative for business and positive for nursing, but insignificant for both.

Columns (8) through (10) alter the control group used to generate counterfactual time trends by estimating time trends that are specific to various college characteristics. These models permit distinct time trends by census division (8), institution state (9), and the interaction between division and Barron's category (10). For instance, if there was an increased demand for engineers from selective colleges on the west coast which happened to coincide with the adoption of differential tuition policies at some west coast schools, then specification (10) would control for this source of omitted variable bias. Identification comes from comparisons between the trends in degree share of adopters and non-adopters among similarly-selective schools in the same region. Specification (9) permits time trends to vary by institution state, exploiting within-state variation in the adoption of differential tuition. The base results are robust to all these alternative control groups. The point estimates for engineering share are remarkably stable and those for business and nursing only become larger in magnitude, though are still insignificant.

\section{Heterogeneity and Student Sorting}

A primary concern voiced by opponents of differential pricing is that certain groups would be particularly affected. For instance, if minority or low-income students are particularly pricesensitive, then they may be dissuaded from entering more high-priced fields. Differential responses would be worrisome given that these fields are particularly lucrative and that there is already concern about underrepresented minority and female representation in many fields. To test for response heterogeneity, I re-estimate the base model separately by gender and race. The outcome variables are the share of all degrees awarded to individuals in each group at time $t$ that

\footnotetext{
${ }^{18}$ Furthermore, the results for specification (6) using the full sample (not just the $+/-4$ year window) are very similar to the base specification. These results are available from the author.
} 
were in engineering, business, and nursing. Table 4 presents these results. The point estimate for the 3-year impact on engineering share is similar for most gender and racial groups, but given the large differences in initial major share across groups, the percent reduction is much larger for women than men and underrepresented minorities than white students. Interestingly, the absolute and proportional response is greatest for Asian students, despite their high initial share in engineering. For business, there is less variation across gender and race in the baseline degree share, so similar absolute effects across groups results in similar proportionate effects for men and women and for black and white students. As for engineering, the effect for Asian students is large both absolutely and proportionately. Contrary to the pattern for these other racial/ethnic groups is the experience of Hispanic students, for which the point estimate is positive (but statistically insignificant). Lastly, Panel C presents the results for nursing. Differences across groups are more difficult to interpret as the estimates are much less precise relative to the initial major share than for engineering and business. But the point estimates are positive (though not statistically significant) for all gender and racial groups. For men, the point estimate is significant and implies an extremely large proportionate increase in the share of men majoring in nursing following the introduction of differential pricing for nursing.

Table 5 presents additional evidence on whether differential pricing altered the characteristics of students who enter impacted fields using individual-level data from the NPSAS. A benefit of the individual data is that I can test for changes in characteristics not available in the aggregate IPEDS data, such as test scores and socioeconomic status. I regress each student characteristic on dummies for being in each impacted major, indicators for whether the institution charged differentially for the majors during the survey year, and interactions 
between major and differential pricing. ${ }^{19}$ In this difference-in-differences specification, coefficients on the interactions test whether the characteristic changed more for the impacted fields than other fields following the introduction of differential pricing. For instance, if women were driven from studying engineering when differential pricing was introduced, the coefficient on the engineering interaction should be negative in column (1). Though the coefficients on the main field dummies indicate substantial differences in student characteristics across fields (men and high SAT math students more likely to enter engineering, high income students more likely to enter business), there are few significant changes in student characteristics following the introduction of differential pricing. There is some evidence that differential pricing for engineering students is associated with fewer Pell recipients entering engineering and shift towards students with higher SAT scores (relative to other students at their institution), but no other changes are significant.

Table 5 also provides suggestive evidence on the extent that students sort across institutions in response to differential pricing. The coefficients on the indicators for differential pricing during the survey year quantify the change in enrolled student characteristics across all other (non-impacted) fields following differential pricing. The overall student body enters with lower SAT scores when differential pricing for engineering is introduced, but there are no other observed changes in student characteristics. Taken at face value, this could suggest that one mechanism through which differential pricing for engineering reduces the number of engineering

\footnotetext{
${ }^{19}$ The models also include a full set of year and institution fixed effects. Qualitative results do not change if I include the major indicator, differential pricing indicator, and interaction for each field one at a time.
} 
graduates is by shifting the enrollment of high SAT freshmen (who are disproportionately more likely to enter engineering) to other universities. ${ }^{20}$

It should be noted that due to the relatively few students in each major and at each institution, these estimates are imprecise and I cannot rule out modest changes in student characteristics at institutions and in impacted majors following the introduction of differential pricing.

\section{E. Financial Aid, Resources, and Major Substitutability}

One way that institutions can use revenue generated by differential pricing is to provide additional financial aid to students in impacted majors, partially offsetting the tuition increase. George-Jackson, Rincon, and Garcia (2011) found that minorities studying engineering at two universities received financial aid packages that offset differential tuition. Table 6 presents estimates of the effect of differential pricing on the share of list price covered by institutional grant aid using the same difference-in-differences model used to examine student characteristics. Institutional grant aid covers $15 \%$ of the tuition list price across our entire sample. Coefficients on the interactions test whether institutional grant aid changed more for the impacted fields than other fields following the introduction of differential pricing. For instance, if business schools redirected the revenue generated from differential pricing to more grant aid for undergraduate business students, the coefficient on the business interaction should be positive. I find no evidence that differential pricing leads to a reallocation of institutional grant aid across majors. Whether controlling for an extensive set of individual controls (SAT score, female, minority, undergraduate level, EFC) or looking at specific student subgroups, the interaction coefficients are never significant.

\footnotetext{
${ }^{20}$ In results available from the author, I also find that the share of students that is full-time, the share of students that are in-state, and the Pell amount per full-time-equivalent student (a proxy for socioeconomic disadvantage) also do not change following the introduction of differential pricing.
} 
A full accounting of changes in resource levels and allocation following the introduction of differential pricing is not feasible due to the absence of within-institution, department-specific resource measures over time for a large sample of universities. However, using university-level measures, I do find that the introduction of differential pricing is associated with higher overall sticker price and lower state appropriations, but no noticeable change in spending on instruction or academic support at the university-level. It should be noted that these aggregate universitylevel measures may provide a poor approximation for the price and resource changes occurring in specific departments or schools within universities. ${ }^{21}$

To further uncover the channels through which my main results operate, I also examined the effect of differential pricing on the degree share of all other fields. These results are presented in Appendix Table A3. There are no clear and robust patterns of substitution between fields following the adoption of differential pricing. For instance, I find no evidence that differential pricing for engineering shifts students towards computer science, math, or other obviously closely related fields; many estimates are imprecise and depend on the specification. Overall, I do find that differential pricing does shift degree production towards fields that earn less on average, though the magnitude is small (a reduction in average earnings of $0.7 \%$ following differential pricing for business) and the estimate is imprecise and not robust.

\section{Implications and Conclusions}

This paper provides the first evidence on the consequences of differential pricing by undergraduate program in postsecondary education. Given the differences in instructional costs and earnings premiums across majors, some view this practice as an equitable and politically feasible alternative to across-the-board tuition and fees increases. I find that differential pricing is associated with a sizable reduction in the fraction of degrees granted in engineering: the elasticity

\footnotetext{
${ }^{21}$ These results are available from the author.
} 
of engineering share with respect to price is -0.51 . Business share is slightly less responsive (elasticity $=-0.30$ ), though this is not significant at conventional levels. Differential pricing for nursing is actually associated with a large increase in the nursing share (elasticity $=+0.97$ ), though this is imprecise and not significantly different from zero. Consistent with the concern of some critics of this development, I also find that women and minorities have larger proportionate effects than male and white students. It does not appear that additional institutional grant aid offsets the increased tuition for impacted majors.

This study has relevance for a number of different policies. Most directly, the results inform the likely consequences of colleges' use of differential pricing. Previous research on the effect of price on college enrollment or choice and the effect of expected earnings on major choice are unlikely to provide much guidance to the likely effects of differential pricing by program. My results suggest that implementing these differentials may indeed impact the fields that students pursue. Furthermore, since differentials may reduce demand, these policies may not raise as much revenue as expected. It is important for colleges to understand how the revenue and student impact of differential pricing compares to alternative pricing schemes such as acrossthe-board tuition increases or tuition increases for wealthier or out-of-state students. This paper informs one side of this calculation.

The experience with differential pricing may also be informative about the likely impact of financial incentives designed to alter students’ field of study. That fact that potential engineering students appear to respond to differential pricing suggests that students’ major choice may also respond to other financial incentives. This study also contributes to our understanding of how students respond to financial incentives at different stages of the college process. Choices may respond to financial incentives differently before college entry, while 
enrolled in lower division coursework, or closer to graduation, though the timing of incentives has received little attention. Though it is difficult to pin-point precisely when college major choices are made, these results suggest that even decisions made during college can be responsive to price. Understanding where financial incentives are strongest (or weakest) informs how they should best be targeted.

This study has a number of limitations that should be addressed in subsequent work. First, I study the experience of many large public research universities, fifty of which adopted differential tuition during the analysis period for engineering, business, or nursing. While these schools represent an important segment of the U.S. postsecondary landscape, their experience may not be typical of other segments, such as smaller public and private colleges, for-profits, and sub-baccalaureate institutions. Future data collection on differentials should target these institutions and examine the consequences.

Second, my data does not permit me to separate demand from supply factors, which combine to determine the sorting of students into majors. Different observed responses across fields may reflect differences in demand parameters, a supply or quality response that differs across fields, or that fields are in different initial equilibrium states since the effects I uncover combine both a demand and supply response. It is possible that additional revenue enables an expansion in the supply of nursing positions while engineering revenue is used to improve quality and attract better (though fewer) students. Uncovering just how and whether programs reallocate resources or increase capacity in response to this new revenue stream would help to interpret my findings and would be a welcome complement to the present study. 


\section{REFERENCE LIST}

Alvarez, Lizette, 2012. “Florida May Reduce Tuition for Select Majors.” New York Times, December 9, 2012.

Arcidiacono, Peter. 2004. Ability Sorting and the Returns to College Major. Journal of Econometrics, 121(1-2): 343-375.

George-Jackson, Casey E., Blanca Rincon, and Mariana Garcia, 2011. “Effects of Differential Tuition on Low-Income Undergraduate Students in Engineering” forthcoming in Journal of Student Aid.

Arcidiacono, Peter, Joseph Hotz, and Songman Kang. 2011. Modeling College Major Choices using Elicited Measures of Expectations and Counterfactuals. Journal of Econometrics, forthcoming.

Babcock, Philip and Mindy Marks. 2011. The falling time cost of college: Evidence from half a century of time use data. Review of Economics and Statistics. 93(2): 468-478.

Becker, Gary S., 1964. Human Capital: A Theoretical and Empirical Analysis with Special Reference to Education. New York: Columbia University Press.

Beffy, Magali, Denis Fougere, and Arnaud Maurel. 2011. Choosing the Field of Study in PostSecondary Education: Do Expected Earnings Matter? The Review of Economics and Statistics, Forthcoming.

Berg, David and Stephen Hoenack, 1988. “The Concept of Cost-Related Tuition and Its Implementation at the University of Minnesota.” The Journal of Higher Education. 58(3): 276-305.

Berger, Mark. 1988. Predicted Future Earnings and Choice of College Major. Industrial and Labor Relations Review, 41(3): 418-29.

Bettinger, Eric. 2004. How Financial Aid Affects Persistence.” In College Choices: The Economics of Where to Go, When to Go, and How to Pay for It, ed. Caroline Hoxby. University of Chicago Press. 
Bound, John and Sarah Turner, 2007. "Cohort crowding: How resources affect collegiate attainment,” Journal of Public Economics, Volume 91, Issues 5-6, June 2007, Pages 877899.

Cornell Higher Education Research Institute, 2011. 2011 Survey of Differential Tuition at Public Higher Education Institutions. http://www.ilr.cornell.edu/cheri/upload/2011CHERISurveyFinal0212.pdf

DesJardins, Stephen and Brian McCall. 2010. Simulating the Effects of Financial Aid Packages on College Student Stopout, Reenrollment Spells, and Graduation Chances. The Review of Higher Education. 33(4): 513-541.

Dynarski, Susan, 2008. Building the Stock of College-Educated Labor." Journal of Human Resources 43:3, pp. 576-610.

Ehrenberg, Ronald G. 2012. “American Higher Education in Transition. Journal of Economic Perspectives. 26(1): 193-216.

Evans, Brent J., 2012. "SMART Money: Do Financial Incentives Encourage College Students to Study Science?” Unpublished working paper. Stanford University.

Goldrick-Rab, Sara, Douglas N. Harris, James Benson and Robert Kelchen. 2011. Conditional Cash Transfers and College Persistence: Evidence from a Randomized Need-Based Grant Program. Institute for Research on Poverty Discussion Paper no. 1393-11

Gordon, Larry. 2009. "UC may hike tuition for some undergraduate majors.” Los Angeles Times. October 12, 2009.

Griffith, Amanda. 2010. Persistence of women and minorities in STEM field majors: Is it the school that matters? Economics of Education Review. 29 (2010): 911-922.

Hoenack, Stephen and William Weiler, 1975. "Cost-Related Tuition Policies and University Enrollments.” Journal of Human Resources. 10(3): 332-360.

Institute of Medicine. The future of nursing: leading change, advancing health. Washington, DC: National Academies Press, 2011.

Jesse, David, 2012, “3\% Proposed Funding Hike for Public Universities Tied to Performance.” Detroit Free Press, February 9, 2012. 
Jacob, Brian, Brian P. McCall, and Kevin Stange, 2013. “College as Country Club: Do Colleges Cater to Students’ Preferences for Consumption.” NBER Working Paper 18745.

Johnson, William R. and Sarah Turner, 2009. "Faculty without Students: Resource Allocation in Higher Education.” Journal of Economic Perspectives. 23(2): 169-189.

Kane, Thomas J., 2006. "Public Intervention in Postsecondary Education” in Eric Hanushek and Finis Welch (eds.) Handbook on the Economics of Education (Amsterdam: Elsevier/NorthHolland, 2006)

Kim, Jeongeun, and Kevin Stange, 2013. "Differential Pricing in the Wake of Tuition Deregulation in Texas Public Universities.” Unpublished working paper, University of Michigan.

Long, Bridget Terry. How Have College Decisions Changed Over Time? An Application of the Conditional Logistic Choice Model. Journal of Econometrics, 121: 271-298

Montmarquette, Claude, Kathy Cannings, and Sophie Mahseredjian. 2002. How Do Young People Choose College Majors? Economics of Education Review, 21(6): 543-556.

Morgan, Rachel, 2010. Summary of the Health Workforce Provisions in the Patient Protection and Affordable Care Act: HR3590. National Conference of State Legislators. Accessed at http://www.ncsl.org/documents/health/HlthWrkfrceProvHR3590.pdf.

National Association of State Budget Officers (NASBO), 2012. State Expenditure Report: Examining Fiscal 2010-2012 State Spending. National Association of State Budget Officers: Washington, D.C.

Nelson, Glen. 2008. Differential tuition by undergraduate major: Its use, amount, and impact on public research universities. Unpublished doctoral dissertation, University of NebraskaLincoln. Lincoln, NE.

Plant, Meagan, 2012. “Ohio Unveils New Funding Plan for 4-year Colleges to Improve Graduation Rates.” Middletown Journal, November 30, 2012.

Redden, Elizabeth. 2007. “Paying by the Program” Inside Higher Ed. March 26, 2007.

Reed, Leslie. 2011. “UNL tuition may vary by majors” Omaha World-Herald. April 27, 2011. 
Rothstein, Jesse and Cecilia Rouse. 2011. Constrained after college: Student loans and earlycareer occupational choices. Journal of Public Economics. 95(2011):149-163.

SHEEO (State Higher Education Executive Officers). 2010. Four-State Cost Study.

Simone, Sean. 2010. Tuition and Fee Differentiation at Degree Granting Postsecondary Education Institutions. An AIR/NCES Data Policy Fellowship Report. May 2010.

Siegfried, John and David Round, 1997. "Differential Fees for Degree Courses in Australian Universities.” In Funding Higher Education: Performance and Diversity, edited by Jonathan Pincus and Paul Miller, 45-62. Canberra: Department of Employment, Education, Training, and Youth Affairs.

Stinebrickner, Ralph and Stinebrickner, Todd R. 2008 The Causal Effect of Studying on Academic Performance. The B.E. Journal of Economic Analysis \& Policy: Vol. 8 (1) (Frontiers), Article 14.

Stinebrickner, Todd, and Ralph Stinebrickner. 2011. "Math or Science? Using Longitudinal Expectations Data to Examine the Process of Choosing a College Major." NBER Working Paper 16869.

Turner, Sarah. 2004. Going to College and Finishing College: Explaining Different Educational

Outcomes."In College Choices: The Economics of Where to Go, When to Go, and How to Pay for It, ed. Caroline Hoxby. University of Chicago Press

University of California Office of the President. 2009. "Differential Fees for Undergraduates by Discipline.” 2010-11 Budget Development Briefing Paper. 10/5/2009.

University of Washington Office of Planning and Budgeting. 2011. "Use of Differential Tuition at Large Public Universities” Planning and Budgeting Brief.

U.S. Department of Education, National Center for Education Statistics. 2003. A Study of Higher Education Instructional Expenditures: The Delaware Study of Instructional Costs and Productivity. NCES 2003-161, by Michael F. Middaugh, Rosalinda Graham, and Abdus Shahid. Project Officer: C. Dennis Carroll. Washington, DC: 2003

Yanikoski, Richard and Richard Wilson. 1984. Differential Pricing of Undergraduate Education. Journal of Higher Education. 55(6): 735-750. 
Wiswall, Matthew and Basit Zafar. 2011. Determinants of College Major Choice: Identification using an Information Experiment. Unpublished working paper. 


\begin{tabular}{|c|c|c|c|c|}
\hline & \multirow[b]{2}{*}{ All schools } & \multirow[b]{2}{*}{$\begin{array}{l}\text { Never had } \\
\text { differential }\end{array}$} & \multicolumn{2}{|c|}{ Had at least one differential } \\
\hline & & & $\begin{array}{l}\text { Timing } \\
\text { known }\end{array}$ & $\begin{array}{l}\text { Timing } \\
\text { unknown }\end{array}$ \\
\hline \multicolumn{5}{|l|}{ Pricing differential } \\
\hline Has differential in engineering during year & 0.11 & 0.00 & 0.29 & $\mathrm{n} / \mathrm{a}$ \\
\hline Has differential in busines during year & 0.12 & 0.00 & 0.30 & $\mathrm{n} / \mathrm{a}$ \\
\hline Has differential in nursing during year & 0.04 & 0.00 & 0.11 & $\mathrm{n} / \mathrm{a}$ \\
\hline \multicolumn{5}{|l|}{ College characteristics } \\
\hline Total BA degrees granted $(1,000)$ & 2.97 & 2.92 & 3.09 & 2.81 \\
\hline Current freshmen enrollment $(1,000)$ & 2.75 & 2.62 & 2.96 & 2.69 \\
\hline In-state tuition + fees (sticker price) $(\$ 1000)$ & 4.76 & 4.72 & 4.90 & 4.54 \\
\hline Out-of-state differential (\% over in-state) & 1.89 & 1.95 & 1.84 & 1.76 \\
\hline Full-time faculty per 100 FTE & 6.34 & 6.10 & 6.55 & 6.88 \\
\hline State appropriations per FTE $(\$ 1000)$ & 10.00 & 10.30 & 9.57 & 9.91 \\
\hline Instructional spending per FTE $(\$ 1000)$ & 9.10 & 9.06 & 9.17 & 9.12 \\
\hline Academic support spending per FTE $(\$ 1000)$ & 2.34 & 2.34 & 2.31 & 2.46 \\
\hline Undergraduates \% full-time & 0.80 & 0.80 & 0.80 & 0.77 \\
\hline Pell grant amount per FTE $(\$ 1000)$ & 0.62 & 0.66 & 0.56 & 0.63 \\
\hline Freshmen enrollment \% instate & 0.81 & 0.84 & 0.78 & 0.76 \\
\hline Most/highly competitive & 0.17 & 0.20 & 0.16 & 0.11 \\
\hline Very competitive & 0.30 & 0.24 & 0.36 & 0.37 \\
\hline Competitive/less/noncompetitive & 0.53 & 0.56 & 0.47 & 0.53 \\
\hline \multicolumn{5}{|l|}{ Share of bachelors degrees awarded in } \\
\hline Engineering & 0.08 & 0.07 & 0.10 & 0.07 \\
\hline Business & 0.18 & 0.17 & 0.19 & 0.18 \\
\hline Nursing & 0.03 & 0.03 & 0.03 & 0.06 \\
\hline Observations & 3,059 & 1,653 & 1,045 & 361 \\
\hline Number of colleges & 161 & 87 & 55 & 19 \\
\hline
\end{tabular}

Notes: Full sample includes observations for 161 public research universities for 19 years (1990 to 2008). Analysis sample includes the 87 non-differential schools and the 55 differential schools for which precise information about the timing of adoption of differential pricing was obtained. Data on differential pricing comes from Nelson (2008), college characteristics come from IPEDS and the Delta Cost Project, and share of bachelors degrees awarded by category comes from IPEDS. 
Table 2. Effect of Differential Tuition on Composition of Degrees Awarded, Main Results

\begin{tabular}{|c|c|c|c|c|c|c|c|c|c|c|c|c|}
\hline & \multicolumn{4}{|c|}{ Dept Var: Share Engineering } & \multicolumn{4}{|c|}{ Dept Var: Share Business } & \multicolumn{4}{|c|}{ Dept Var: Share Nursing } \\
\hline & $(1)$ & $(2)$ & (3) & $(4)$ & (5) & $(6)$ & $(7)$ & $(8)$ & (9) & $(10)$ & $(11)$ & $(12)$ \\
\hline Have differential in year & $\begin{array}{l}0.059 * * \\
(0.028)\end{array}$ & $\begin{array}{c}-0.011^{\star \star} \\
(0.005)\end{array}$ & & & $\begin{array}{l}-0.001 \\
(0.015)\end{array}$ & $\begin{array}{l}-0.008 \\
(0.005)\end{array}$ & & & $\begin{array}{l}0.015^{\star \star} \\
(0.006)\end{array}$ & $\begin{array}{l}-0.001 \\
(0.002)\end{array}$ & & \\
\hline Adopted differential 0-2 years earlier & & & $\begin{array}{l}-0.004 \\
(0.004)\end{array}$ & $\begin{array}{c}-0.004^{\star *} \\
(0.002)\end{array}$ & & & $\begin{array}{l}-0.004 \\
(0.004)\end{array}$ & $\begin{array}{l}-0.004 \\
(0.004)\end{array}$ & & & $\begin{array}{l}-0.003 \\
(0.002)\end{array}$ & $\begin{array}{c}0.000 \\
(0.002)\end{array}$ \\
\hline Adopted differential 3+ years earlier & & & $\begin{array}{c}-0.017^{\star *} \\
(0.007)\end{array}$ & $\begin{array}{c}-0.011^{\star * *} \\
(0.004)\end{array}$ & & & $\begin{array}{l}-0.012 \\
(0.009)\end{array}$ & $\begin{array}{l}-0.008 \\
(0.007)\end{array}$ & & & $\begin{array}{c}0.004 \\
(0.003)\end{array}$ & $\begin{array}{c}0.008 \\
(0.006)\end{array}$ \\
\hline Constant & $\begin{array}{c}0.079 * * * \\
(0.009)\end{array}$ & $\begin{array}{c}0.097^{\star \star *} \\
(0.002)\end{array}$ & $\begin{array}{c}0.097^{\star \star *} \\
(0.002)\end{array}$ & $\begin{array}{c}0.088^{\star * *} \\
(0.002)\end{array}$ & $\begin{array}{c}0.181^{\star * \star} \\
(0.007)\end{array}$ & $\begin{array}{c}0.213^{\star \star \star} \\
(0.003)\end{array}$ & $\begin{array}{c}0.213^{\star \star \star} \\
(0.003)\end{array}$ & $\begin{array}{c}0.210^{* * *} \\
(0.004)\end{array}$ & $\begin{array}{c}0.027^{\star \star *} \\
(0.003)\end{array}$ & $\begin{array}{c}0.023^{* * *} \\
(0.001)\end{array}$ & $\begin{array}{c}0.023^{\star \star \star} \\
(0.001)\end{array}$ & $\begin{array}{c}0.021^{\star \star \star} \\
(0.001)\end{array}$ \\
\hline Sample & All years & All years & All years & $+/-4$ years & All years & All years & All years & $+/-4$ years & All years & All years & All years & $+/-4$ years \\
\hline Additional controls & None & $\begin{array}{l}\text { Year FE } \\
\text { School FE }\end{array}$ & $\begin{array}{l}\text { Year FE } \\
\text { School FE }\end{array}$ & $\begin{array}{l}\text { Year FE } \\
\text { School FE }\end{array}$ & None & $\begin{array}{l}\text { Year FE } \\
\text { School FE }\end{array}$ & $\begin{array}{l}\text { Year FE } \\
\text { School FE }\end{array}$ & $\begin{array}{l}\text { Year FE } \\
\text { School FE }\end{array}$ & None & $\begin{array}{l}\text { Year FE } \\
\text { School FE }\end{array}$ & $\begin{array}{l}\text { Year FE } \\
\text { School FE }\end{array}$ & $\begin{array}{l}\text { Year FE } \\
\text { School FE }\end{array}$ \\
\hline Observations & 2,698 & 2,698 & 2,698 & 2,304 & 2,698 & 2,698 & 2,698 & 2,234 & 2,698 & 2,698 & 2,698 & 2,489 \\
\hline R-squared & 0.027 & 0.979 & 0.979 & 0.978 & 0.000 & 0.906 & 0.906 & 0.913 & 0.008 & 0.903 & 0.903 & 0.918 \\
\hline Outcome mean & 0.147 & 0.147 & 0.147 & 0.147 & 0.195 & 0.195 & 0.195 & 0.195 & 0.044 & 0.044 & 0.044 & 0.044 \\
\hline
\end{tabular}

Notes: Robust standard errors clustered by school in parentheses. ${ }^{* *} p<0.01,{ }^{* *} p<0.05,{ }^{*} p<0.1$. All specifications include 142 schools, though the number of schools that adopted a differential tuition policy varies between fields. Model is estimated using OLS. Outcome mean is for colleges that eventually adopted tuition differentials in the pre-differential period. 
Table 3. Robustness of Main Results to Choice of Control Group and Other Covariates

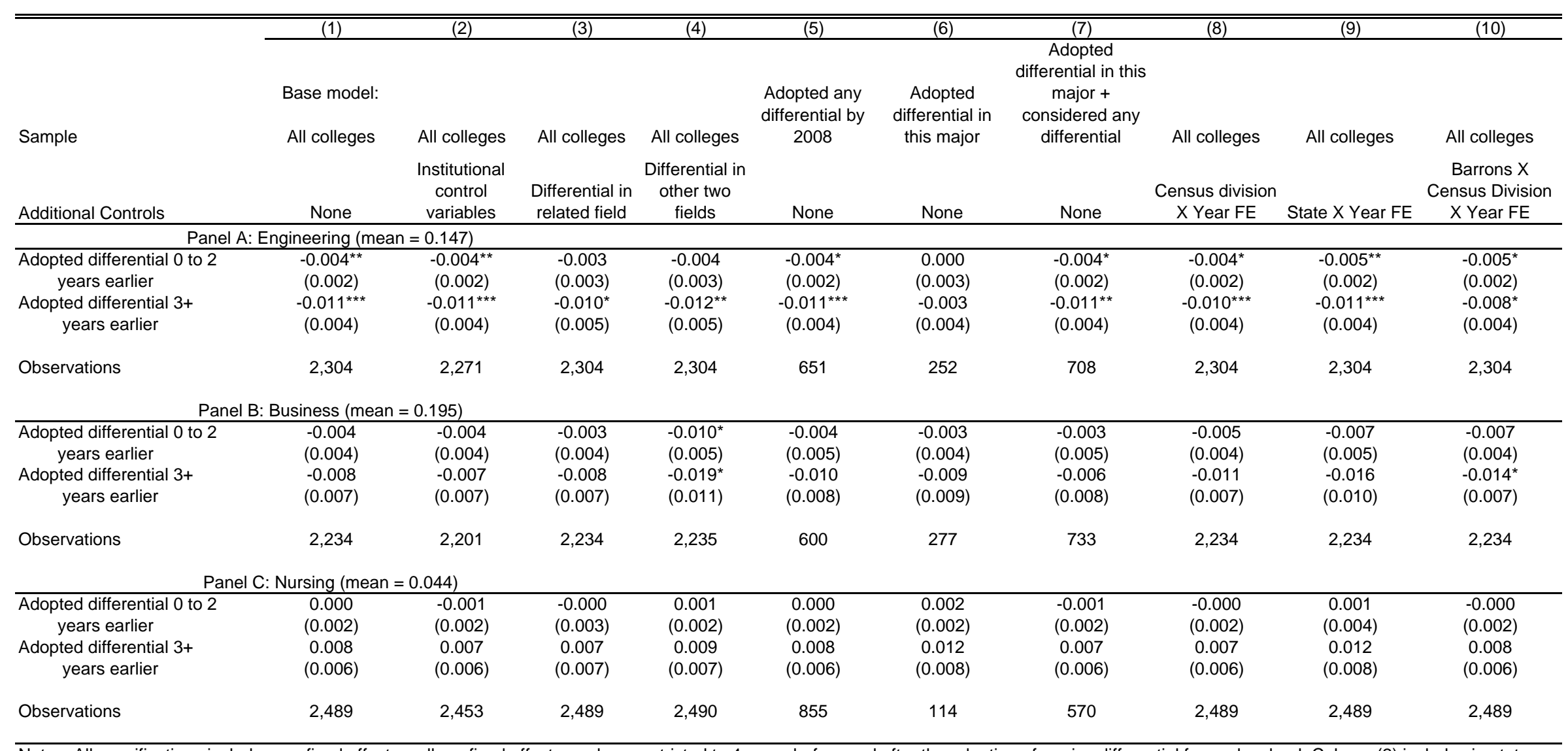

Notes: All specifications include year fixed effects, college fixed effects, and are restricted to 4 years before and after the adoption of a price differential for each school. Column (2) includes in-state list tuition price, out-of-state tuition differential, full-time faculty to student ratio, state appropriations per student, instructional and academic support spending per student, fraction of students that are full-time, fraction in-state, and the average Pell grant per student. Column (3) includes controls for differential pricing for architecture, computer science, or physical science (Panel A), liberal arts (Panel B), or other health professions and physical therapy (Panel C). Robust standard errors clustered by school in parentheses. ${ }^{* \star *} p<0.01,{ }^{\star *} p<0.05,{ }^{*} p<0.1$. Outcome mean is for colleges that eventually adopted tuition differentials in the pre-differential period. 
Table 4. Response Heterogeneity by Gender and Race

\begin{tabular}{|c|c|c|c|c|c|c|c|}
\hline & $\begin{array}{l}\text { Women } \\
\text { (1) }\end{array}$ & $\begin{array}{l}\text { Men } \\
(2)\end{array}$ & $\begin{array}{l}\text { Black } \\
\text { (3) }\end{array}$ & $\begin{array}{l}\text { White } \\
\text { (4) }\end{array}$ & $\begin{array}{l}\text { Hispanic } \\
\text { (5) }\end{array}$ & $\begin{array}{l}\text { Asian } \\
(6)\end{array}$ & $\begin{array}{l}\text { Other race } \\
\text { (7) }\end{array}$ \\
\hline & \multicolumn{7}{|c|}{ Panel A: Engineering } \\
\hline Outcome mean & 0.074 & 0.215 & 0.095 & 0.128 & 0.121 & 0.196 & 0.200 \\
\hline $\begin{array}{c}\text { Adopted differential } 0 \text { to } 2 \\
\text { years earlier }\end{array}$ & $\begin{array}{l}-0.003^{\star *} \\
(0.001)\end{array}$ & $\begin{array}{l}-0.006^{\star} \\
(0.003)\end{array}$ & $\begin{array}{l}-0.013^{*} \\
(0.007)\end{array}$ & $\begin{array}{l}-0.004 \\
(0.003)\end{array}$ & $\begin{array}{l}-0.009 \\
(0.013)\end{array}$ & $\begin{array}{l}-0.031^{\star *} \\
(0.014)\end{array}$ & $\begin{array}{l}-0.002 \\
(0.009)\end{array}$ \\
\hline $\begin{array}{c}\text { Adopted differential 3+ } \\
\text { years earlier }\end{array}$ & $\begin{array}{l}-0.010^{\star \star} \\
(0.004)\end{array}$ & $\begin{array}{l}-0.012^{\star *} \\
(0.005)\end{array}$ & $\begin{array}{l}-0.015 \\
(0.011)\end{array}$ & $\begin{array}{l}-0.012^{\star \star \star} \\
(0.004)\end{array}$ & $\begin{array}{l}-0.014 \\
(0.018)\end{array}$ & $\begin{array}{l}-0.050^{\star \star} \\
(0.019)\end{array}$ & $\begin{array}{l}-0.012 \\
(0.016)\end{array}$ \\
\hline $3+$ year coefficient/mean & -0.135 & -0.056 & -0.158 & -0.094 & -0.116 & -0.255 & -0.060 \\
\hline \multirow[t]{2}{*}{ Observations } & 2,304 & 2,304 & 1,709 & 1,712 & 1,695 & 1,707 & 1,705 \\
\hline & \multicolumn{7}{|c|}{ Panel B: Business } \\
\hline Outcome mean & 0.163 & 0.234 & 0.165 & 0.183 & 0.170 & 0.246 & 0.244 \\
\hline $\begin{array}{c}\text { Adopted differential } 0 \text { to } 2 \\
\text { years earlier }\end{array}$ & $\begin{array}{l}-0.003 \\
(0.004)\end{array}$ & $\begin{array}{l}-0.005 \\
(0.005)\end{array}$ & $\begin{array}{l}-0.002 \\
(0.011)\end{array}$ & $\begin{array}{l}-0.004 \\
(0.004)\end{array}$ & $\begin{array}{c}0.001 \\
(0.013)\end{array}$ & $\begin{array}{l}-0.017 \\
(0.017)\end{array}$ & $\begin{array}{l}-0.018 \\
(0.012)\end{array}$ \\
\hline $\begin{array}{c}\text { Adopted differential 3+ } \\
\text { years earlier }\end{array}$ & $\begin{array}{l}-0.008 \\
(0.006)\end{array}$ & $\begin{array}{l}-0.009 \\
(0.008)\end{array}$ & $\begin{array}{l}-0.006 \\
(0.013)\end{array}$ & $\begin{array}{l}-0.009 \\
(0.006)\end{array}$ & $\begin{array}{c}0.015 \\
(0.016)\end{array}$ & $\begin{array}{l}-0.026 \\
(0.022)\end{array}$ & $\begin{array}{l}-0.030^{*} \\
(0.016)\end{array}$ \\
\hline $3+$ year coefficient/mean & -0.049 & -0.038 & -0.036 & -0.049 & 0.088 & -0.106 & -0.123 \\
\hline \multirow[t]{2}{*}{ Observations } & 2,234 & 2,234 & 1,665 & 1,668 & 1,651 & 1,663 & 1,661 \\
\hline & \multicolumn{7}{|c|}{ Panel C: Nursing } \\
\hline Outcome mean & 0.070 & 0.011 & 0.037 & 0.049 & 0.037 & 0.033 & 0.022 \\
\hline $\begin{array}{c}\text { Adopted differential } 0 \text { to } 2 \\
\text { years earlier }\end{array}$ & $\begin{array}{l}-0.001 \\
(0.003)\end{array}$ & $\begin{array}{l}0.002^{\star *} \\
(0.001)\end{array}$ & $\begin{array}{c}0.010 \\
(0.011)\end{array}$ & $\begin{array}{c}0.000 \\
(0.002)\end{array}$ & $\begin{array}{c}0.005 \\
(0.006)\end{array}$ & $\begin{array}{c}0.004 \\
(0.004)\end{array}$ & $\begin{array}{c}0.003 \\
(0.004)\end{array}$ \\
\hline $\begin{array}{c}\text { Adopted differential 3+ } \\
\text { years earlier }\end{array}$ & $\begin{array}{c}0.008 \\
(0.009)\end{array}$ & $\begin{array}{l}0.006^{\star *} \\
(0.003)\end{array}$ & $\begin{array}{l}0.009 \\
(0.012)\end{array}$ & $\begin{array}{c}0.001 \\
(0.009)\end{array}$ & $\begin{array}{c}0.004 \\
(0.012)\end{array}$ & $\begin{array}{l}0.008 \\
(0.013)\end{array}$ & $\begin{array}{l}0.019^{*} \\
(0.010)\end{array}$ \\
\hline $3+$ year coefficient/mean & 0.114 & 0.545 & 0.243 & 0.020 & 0.108 & 0.242 & 0.864 \\
\hline Observations & 2,489 & 2,489 & 1,847 & 1,850 & 1,833 & 1,845 & 1,843 \\
\hline
\end{tabular}

Notes: All specifications include year fixed effects, college fixed effects, and are restricted to 4 years before and after the adoption of a price differential for each school. Regressions for race groups are limited to 1995-2008. Robust standard errors clustered by school in parentheses. ${ }^{\star \star *} p<0.01,{ }^{* \star} p<0.05,{ }^{*} p<0.1$. Outcome mean is for the specified group at colleges that eventually adopted tuition differentials in the pre-differential period. 
Table 5. Effect of Differential Pricing on Student Composition in Impacted Fields using NPSAS Microdata

\begin{tabular}{|c|c|c|c|c|c|c|c|}
\hline & \multicolumn{7}{|c|}{ Outcomes (sample mean) } \\
\hline & Female $(0.518)$ & $\begin{array}{c}\text { Minority } \\
(0.175)\end{array}$ & $\begin{array}{c}\text { Pell } \\
(0.228)\end{array}$ & $\begin{array}{c}\text { SAT math } \\
(0.098)\end{array}$ & $\begin{array}{c}\text { SAT verbal } \\
(0.056)\end{array}$ & $\begin{array}{c}\text { Income, } \\
\text { Sthousands } \\
(81.71)\end{array}$ & $\begin{array}{c}\text { EFC, } \\
\text { Sthousands } \\
(14.42)\end{array}$ \\
\hline & (1) & $(2)$ & (3) & (4) & (5) & (6) & (7) \\
\hline \multirow{6}{*}{ (Engineering major) $\mathrm{X}$ (Have engineering differential) } & $-0.373 * * *$ & -0.001 & -0.007 & $0.520 * * *$ & -0.031 & 7.116 & 0.308 \\
\hline & $(0.016)$ & $(0.013)$ & $(0.017)$ & $(0.037)$ & $(0.037)$ & $(6.038)$ & $(0.728)$ \\
\hline & -0.013 & -0.003 & 0.020 & $-0.214^{* *}$ & $-0.158^{*}$ & 0.620 & 0.495 \\
\hline & $(0.029)$ & $(0.019)$ & $(0.017)$ & $(0.093)$ & $(0.094)$ & $(4.661)$ & $(0.896)$ \\
\hline & 0.013 & -0.015 & $-0.043 *$ & $0.198 * *$ & $0.243 * * *$ & -2.959 & 1.363 \\
\hline & $(0.028)$ & $(0.028)$ & $(0.023)$ & $(0.081)$ & $(0.071)$ & (7.722) & (1.339) \\
\hline \multirow[t]{2}{*}{ Business major } & $-0.129 * * *$ & 0.011 & $-0.040 * * *$ & $0.103 * * *$ & $-0.208 * * *$ & $10.164 * * *$ & $2.738 * * *$ \\
\hline & $(0.016)$ & $(0.011)$ & $(0.011)$ & (0.029) & $(0.031)$ & $(2.008)$ & $(0.529)$ \\
\hline \multirow[t]{2}{*}{ Have business differential } & -0.008 & -0.018 & -0.029 & 0.052 & 0.168 & 5.543 & 0.463 \\
\hline & $(0.034)$ & $(0.023)$ & $(0.025)$ & $(0.072)$ & $(0.112)$ & $(5.260)$ & (1.193) \\
\hline \multirow[t]{2}{*}{ (Business major) X (Have business differential) } & 0.025 & -0.015 & -0.005 & -0.033 & 0.029 & -4.886 & -1.146 \\
\hline & $(0.031)$ & $(0.024)$ & $(0.023)$ & $(0.054)$ & $(0.057)$ & $(4.343)$ & $(1.208)$ \\
\hline \multirow[t]{2}{*}{ Health major } & $0.194^{* * *}$ & 0.008 & -0.008 & $-0.178 * * *$ & $-0.282 * * *$ & -2.968 & -0.686 \\
\hline & $(0.018)$ & $(0.012)$ & $(0.013)$ & $(0.045)$ & $(0.042)$ & $(1.870)$ & $(0.464)$ \\
\hline \multirow[t]{2}{*}{ Have health differential } & -0.000 & -0.027 & $0.060 * *$ & 0.073 & -0.120 & -3.457 & -0.490 \\
\hline & $(0.042)$ & $(0.029)$ & $(0.030)$ & $(0.127)$ & $(0.156)$ & $(6.241)$ & $(1.666)$ \\
\hline \multirow[t]{2}{*}{ (Health major) X (Have health differential) } & $0.099 *$ & -0.016 & 0.041 & -0.023 & -0.012 & 0.202 & 0.392 \\
\hline & $(0.054)$ & $(0.036)$ & $(0.075)$ & $(0.093)$ & $(0.135)$ & (8.019) & (2.178) \\
\hline Observations & 18,105 & 18,105 & 18,105 & 12,202 & 12,202 & 18,105 & 18,105 \\
\hline R-squared & 0.096 & 0.125 & 0.054 & 0.232 & 0.177 & 0.051 & 0.054 \\
\hline
\end{tabular}

Notes: All specifications include year fixed and institution fixed effects. Sample includes only full-time, full-year students attending one of 142 institutions with complete

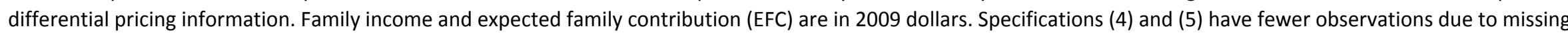
SAT information for some students. Robust standard errors clustered by school in parentheses. ${ }^{* * *} p<0.01,{ }^{* *} p<0.05,{ }^{*} p<0.1$. 
Table 6. Effect of Differential Pricing on Institutional Aid to Students in Impacted Fields

\begin{tabular}{|c|c|c|c|c|c|c|}
\hline & \multicolumn{6}{|c|}{$\begin{array}{l}\text { Dependent variable: } \\
\text { (Institutional grants) / (list tuition+fees) }\end{array}$} \\
\hline & \multicolumn{2}{|c|}{ All students } & \multirow{2}{*}{$\begin{array}{c}\text { In-state } \\
(3)\end{array}$} & \multirow{2}{*}{$\begin{array}{c}\text { Lower } \\
\text { division } \\
(4)\end{array}$} & \multirow{2}{*}{$\begin{array}{c}\begin{array}{c}\text { Upper } \\
\text { division }\end{array} \\
(5)\end{array}$} & \multirow{2}{*}{$\begin{array}{c}\begin{array}{c}\text { Fourth } \\
\text { year }\end{array} \\
(6)\end{array}$} \\
\hline & (1) & (2) & & & & \\
\hline \multirow[t]{2}{*}{ Engineering major } & $0.042^{* *}$ & $0.033^{* *}$ & $0.048 * * *$ & 0.027 & $0.045^{* *}$ & 0.037 \\
\hline & $(0.016)$ & $(0.016)$ & $(0.018)$ & $(0.025)$ & $(0.021)$ & $(0.024)$ \\
\hline \multirow[t]{2}{*}{ Have engineering differential } & -0.020 & -0.013 & -0.028 & -0.034 & -0.004 & -0.002 \\
\hline & $(0.033)$ & $(0.033)$ & $(0.032)$ & $(0.046)$ & $(0.038)$ & $(0.034)$ \\
\hline \multirow[t]{2}{*}{ (Engineering major) $\mathrm{X}$ (Have engineering differential) } & -0.012 & -0.016 & 0.001 & 0.014 & -0.031 & -0.009 \\
\hline & $(0.019)$ & $(0.019)$ & $(0.022)$ & $(0.035)$ & $(0.026)$ & $(0.038)$ \\
\hline \multirow{2}{*}{ Business major } & $-0.019 * *$ & -0.011 & $-0.019 *$ & -0.023 & -0.017 & -0.018 \\
\hline & $(0.009)$ & $(0.009)$ & $(0.011)$ & $(0.014)$ & $(0.013)$ & $(0.020)$ \\
\hline \multirow[t]{2}{*}{ Have business differential } & 0.018 & 0.006 & 0.022 & 0.059 & -0.009 & 0.021 \\
\hline & $(0.041)$ & $(0.043)$ & $(0.036)$ & $(0.038)$ & $(0.057)$ & $(0.051)$ \\
\hline \multirow[t]{2}{*}{ (Business major) $\mathrm{X}$ (Have business differential) } & 0.014 & 0.015 & 0.021 & 0.034 & -0.008 & 0.033 \\
\hline & $(0.018)$ & $(0.017)$ & $(0.016)$ & $(0.028)$ & $(0.026)$ & $(0.043)$ \\
\hline \multirow[t]{2}{*}{ Health major } & -0.013 & -0.009 & -0.019 & -0.014 & -0.012 & -0.011 \\
\hline & $(0.012)$ & $(0.012)$ & $(0.012)$ & $(0.018)$ & $(0.014)$ & (0.018) \\
\hline \multirow[t]{2}{*}{ Have health differential } & -0.016 & -0.009 & -0.023 & -0.000 & -0.041 & -0.081 \\
\hline & $(0.044)$ & $(0.046)$ & $(0.043)$ & $(0.065)$ & (0.059) & $(0.053)$ \\
\hline \multirow[t]{2}{*}{ (Health major) X (Have health differential) } & 0.009 & 0.006 & -0.003 & -0.019 & 0.028 & 0.024 \\
\hline & $(0.025)$ & $(0.025)$ & $(0.026)$ & $(0.025)$ & $(0.046)$ & $(0.068)$ \\
\hline Additional controls & No & Yes & No & No & No & No \\
\hline Observations & 18,039 & 18,039 & 15,693 & 7,010 & 11,029 & 7,369 \\
\hline R-squared & 0.062 & 0.089 & 0.071 & 0.090 & 0.070 & 0.087 \\
\hline Outcome mean & 0.150 & 0.150 & 0.151 & 0.165 & 0.138 & 0.144 \\
\hline
\end{tabular}

Notes: All specifications include year fixed and institution fixed effects. Sample includes only full-time, full-year students attending one of 142 institutions with complete differential pricing information. Additional controls in specification (2) include female, minority, normalized SAT math and verbal score, dummy for missing SAT score, undergraduate level, instate, and expected famility contribution. Robust standard errors clustered by school in parentheses. ${ }^{* * *} p<0.01, * * p<0.05, * p<0.1$ 
Table A1. Institutions with Differential Pricing for Engineering, Business, and Nursing in 2008

\begin{tabular}{|c|c|c|c|c|}
\hline \multirow[b]{2}{*}{ Institution } & \multirow[b]{2}{*}{ Year adopted } & \multicolumn{3}{|c|}{ Amount of differential (\% over base tuition) } \\
\hline & & Engineering & Business & Nursing \\
\hline University of South Alabama & 2008 & 8 & & \\
\hline University of Arkansas Main Campus & 2000 & 16 & 14 & \\
\hline University of Arkansas at Little Rock & 2001 & & 3 & \\
\hline University of Arizona & 1993 & 12 & 16 & \\
\hline Colorado State University & 2006 & 6 & 9 & \\
\hline University of Colorado Denver & 1989 & 14 & 2 & 147 \\
\hline University of Colorado at Boulder & 1984 & 38 & 59 & \\
\hline University of Northern Colorado & 2006 & & 7 & 5 \\
\hline University of Hawaii at Manoa & 2007 & & 12 & 39 \\
\hline lowa State University & 2007 & 19 & & \\
\hline University of lowa & 2007 & 19 & & \\
\hline University of Illinois at Chicago & 1992 & 25 & 8 & 26 \\
\hline University of Illinois at Urbana-Champaign & 1994 & 45 & 45 & \\
\hline Indiana University-Purdue University-Indianapolis & 2008 & & 10 & 16 \\
\hline Purdue University-Main Campus & 1999 & 8 & 13 & \\
\hline Kansas State University & 2003 & 15 & 8 & \\
\hline University of Kansas & 1994 & 16 & 40 & \\
\hline University of Kentucky & 2005 & & 6 & \\
\hline University of Louisville & 2004 & 3 & & \\
\hline Louisiana Tech University & 2006 & & 3 & 4 \\
\hline Michigan Technological University & 2004 & 11 & & \\
\hline Oakland University & 2005 & & & 2 \\
\hline University of Michigan-Ann Arbor & 1989 & 7 & & \\
\hline Missouri University of Science and Technology & 1996 & 23 & 23 & \\
\hline Montana State University & 2003 & 5 & 8 & 8 \\
\hline The University of Montana & 2001 & & 22 & \\
\hline North Dakota State University-Main Campus & 1998 & 13 & & 12 \\
\hline University of Nebraska-Lincoln & 2004 & 24 & & \\
\hline University of New Hampshire-Main Campus & 1991 & 8 & 8 & \\
\hline Rutgers University-New Brunswick & 1992 & 11 & 2 & \\
\hline Rutgers University-Newark & 1993 & & 4 & \\
\hline Miami University-Oxford & 2007 & & 7 & \\
\hline Oregon State University & 1994 & 30 & & \\
\hline Portland State University & 1994 & 24 & 7 & \\
\hline University of Oregon & 1999 & & 10 & \\
\hline Pennsylvania State University-Main Campus & 2008 & 6 & 6 & 20 \\
\hline Temple University & 1989 & & 2 & 21 \\
\hline Clemson University & 2006 & & 17 & \\
\hline University of South Dakota & 2005 & & 30 & 58 \\
\hline University of Memphis & 2002 & 10 & 12 & \\
\hline The University of Texas at Arlington & 2004 & 4 & 13 & 8 \\
\hline The University of Texas at Austin & 2003 & 12 & 16 & 8 \\
\hline The University of Texas at Dallas & 2005 & 15 & & \\
\hline The University of Texas at El Paso & 2000 & & & 2 \\
\hline University of Houston & 2005 & 6 & 6 & \\
\hline University of Utah & 2007 & & 35 & \\
\hline Utah State University & 2003 & 2 & 31 & \\
\hline Virginia Commonwealth University & 2008 & 31 & 6 & \\
\hline Virginia Polytechnic Institute and State University & 2008 & 12 & & \\
\hline University of Wisconsin-Madison & 2008 & & 16 & \\
\hline University of Wisconsin-Milwaukee & 2005 & 9 & 9 & 13 \\
\hline
\end{tabular}

Source: Glen Nelson. Blank indicates that no differential for this particular field. 
Table A2. Effect of Differential Tuition on Composition of Degrees Awarded, Log Results

\begin{tabular}{|c|c|c|c|c|c|c|}
\hline & \multicolumn{2}{|c|}{$\begin{array}{l}\text { Log(Eng Degrees) } \\
\end{array}$} & \multicolumn{2}{|c|}{ Log(Bus Degrees) } & \multicolumn{2}{|c|}{ Log(Nurse Degrees) } \\
\hline & $(1)$ & $(2)$ & $(3)$ & $(4)$ & $(5)$ & $(6)$ \\
\hline \multirow[t]{2}{*}{ Adopted differential 0-2 years earlier } & $-0.056^{\star *}$ & -0.033 & $-0.059 * \star$ & -0.024 & -0.037 & -0.038 \\
\hline & $(0.026)$ & $(0.025)$ & $(0.024)$ & $(0.022)$ & $(0.039)$ & $(0.039)$ \\
\hline \multirow[t]{2}{*}{ Adopted differential 3+ years earlier } & $-0.100 * \star \star$ & $-0.071^{\star}$ & -0.058 & -0.035 & 0.066 & 0.055 \\
\hline & $(0.037)$ & $(0.039)$ & $(0.038)$ & $(0.038)$ & $(0.088)$ & $(0.097)$ \\
\hline \multirow[t]{2}{*}{ Log(Total Degrees) } & & $1.169 * * \star$ & & $1.082^{\star \star \star}$ & & $0.874^{\star \star \star}$ \\
\hline & & $(0.151)$ & & $(0.077)$ & & $(0.122)$ \\
\hline \multirow[t]{2}{*}{ Constant } & $5.062^{\star \star \star}$ & 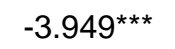 & $6.033^{\star \star *}$ & $-2.258^{\star \star \star}$ & $4.282^{\star \star *}$ & $-2.507^{\star \star \star}$ \\
\hline & $(0.070)$ & $(1.180)$ & $(0.025)$ & $(0.594)$ & $(0.047)$ & $(0.949)$ \\
\hline Sample & $+/-4$ years & $+/-4$ years & $+/-4$ years & $+/-4$ years & $+/-4$ years & $+/-4$ years \\
\hline \multirow[t]{2}{*}{ Additional controls } & Year FE & Year FE & Year FE & Year FE & Year FE & Year FE \\
\hline & School FE & School FE & School FE & School FE & School FE & School FE \\
\hline Observations & 1,804 & 1,804 & 2,127 & 2,127 & 1,425 & 1,425 \\
\hline R-squared & 0.940 & 0.950 & 0.948 & 0.963 & 0.803 & 0.820 \\
\hline Outcome mean & 5.709 & 5.709 & 6.280 & 6.280 & 4.784 & 4.784 \\
\hline
\end{tabular}

Notes: Robust standard errors clustered by school in parentheses. ${ }^{* *} p<0.01,{ }^{* \star} p<0.05,{ }^{*} p<0.1$. All specifications initially include 142 schools, though the number of schools that adopted a differential tuition policy varies between fields and school-year observations with zero degrees awarded in the specified field are dropped. Model is estimated using OLS. Outcome mean is for colleges that eventually adopted tuition differentials in the pre-differential period. 
Table A3. Effect of Differential Pricing on Detailed Composition of Degrees Awarded and Average Earnings

\begin{tabular}{|c|c|c|c|c|c|c|c|c|c|}
\hline & \multirow{3}{*}{$\begin{array}{c}\text { Outcome } \\
\text { mean }\end{array}$} & \multicolumn{2}{|c|}{ Engineering diff } & \multirow{3}{*}{$\begin{array}{c}\text { Outcome } \\
\text { mean }\end{array}$} & \multirow{2}{*}{\multicolumn{2}{|c|}{$\begin{array}{l}\text { Business diff } \\
3+\text { years ago }\end{array}$}} & \multirow{3}{*}{$\begin{array}{l}\text { Outcome } \\
\text { mean }\end{array}$} & \multirow{2}{*}{\multicolumn{2}{|c|}{$\begin{array}{c}\text { Nursing diff } \\
3+\text { years ago }\end{array}$}} \\
\hline & & \multicolumn{2}{|c|}{$3+$ years ago } & & & & & & \\
\hline & & Coeff & SE & & Coeff & SE & & Coeff & SE \\
\hline \multicolumn{10}{|c|}{ Panel A: No controls for simultaneous differential in other two fields } \\
\hline Business & 0.185 & 0.003 & $(0.006)$ & 0.195 & -0.008 & $(0.007)$ & 0.194 & -0.008 & $(0.010)$ \\
\hline Computer science & 0.031 & 0.001 & $(0.004)$ & 0.025 & 0.002 & $(0.002)$ & 0.022 & $0.005^{* *}$ & $(0.002)$ \\
\hline Education & 0.054 & $0.010 * *$ & $(0.005)$ & 0.061 & $0.010^{*}$ & $(0.005)$ & 0.068 & 0.006 & $(0.006)$ \\
\hline Engineering & 0.147 & $-0.011 * * *$ & $(0.004)$ & 0.096 & $-0.008 * *$ & $(0.003)$ & 0.085 & $-0.012 * *$ & $(0.006)$ \\
\hline Health & 0.041 & 0.001 & $(0.003)$ & 0.048 & -0.001 & $(0.003)$ & 0.061 & -0.001 & $(0.005)$ \\
\hline Humanities & 0.112 & -0.000 & $(0.004)$ & 0.133 & -0.003 & $(0.004)$ & 0.130 & -0.003 & $(0.005)$ \\
\hline Life science & 0.079 & 0.002 & $(0.006)$ & 0.079 & 0.002 & $(0.006)$ & 0.085 & 0.012 & $(0.011)$ \\
\hline Math & 0.010 & 0.000 & $(0.001)$ & 0.010 & -0.000 & $(0.001)$ & 0.009 & -0.002 & $(0.002)$ \\
\hline Nursing & 0.027 & -0.002 & $(0.002)$ & 0.026 & -0.001 & $(0.002)$ & 0.044 & 0.008 & $(0.006)$ \\
\hline Other professional & 0.134 & -0.002 & $(0.005)$ & 0.121 & 0.006 & $(0.006)$ & 0.131 & -0.003 & $(0.006)$ \\
\hline Physical science & 0.016 & 0.000 & $(0.001)$ & 0.017 & 0.001 & $(0.001)$ & 0.016 & 0.000 & $(0.001)$ \\
\hline Social science & 0.151 & -0.004 & $(0.003)$ & 0.175 & -0.001 & $(0.003)$ & 0.146 & -0.004 & $(0.005)$ \\
\hline Vocational technical & 0.014 & 0.001 & $(0.001)$ & 0.014 & 0.001 & $(0.001)$ & 0.011 & 0.000 & $(0.001)$ \\
\hline Average earnings & 76,453 & $-484^{* *}$ & $(187)$ & 75,291 & $-569 * * *$ & (216) & 74,486 & $-417^{*}$ & $(243)$ \\
\hline \multicolumn{10}{|c|}{ Panel B: Controls for simultaneous differential in other two fields } \\
\hline Business & 0.185 & $0.029 * *$ & $(0.013)$ & 0.195 & $-0.019 *$ & $(0.011)$ & 0.194 & -0.005 & $(0.011)$ \\
\hline Computer science & 0.031 & -0.002 & $(0.006)$ & 0.025 & 0.003 & $(0.003)$ & 0.022 & 0.005 & $(0.004)$ \\
\hline Education & 0.054 & 0.007 & $(0.009)$ & 0.061 & 0.010 & $(0.009)$ & 0.068 & 0.002 & $(0.007)$ \\
\hline Engineering & 0.147 & $-0.012^{* *}$ & $(0.005)$ & 0.096 & 0.000 & $(0.009)$ & 0.085 & -0.002 & $(0.008)$ \\
\hline Health & 0.041 & 0.006 & $(0.006)$ & 0.048 & -0.005 & $(0.005)$ & 0.061 & -0.001 & $(0.005)$ \\
\hline Humanities & 0.112 & 0.007 & $(0.006)$ & 0.133 & -0.002 & $(0.006)$ & 0.130 & -0.002 & $(0.006)$ \\
\hline Life science & 0.079 & -0.005 & $(0.008)$ & 0.079 & -0.009 & $(0.008)$ & 0.085 & 0.011 & $(0.010)$ \\
\hline Math & 0.010 & 0.000 & $(0.001)$ & 0.010 & -0.001 & $(0.001)$ & 0.009 & -0.003 & $(0.002)$ \\
\hline Nursing & 0.027 & -0.002 & $(0.002)$ & 0.026 & -0.002 & $(0.002)$ & 0.044 & 0.009 & $(0.007)$ \\
\hline Other professional & 0.134 & -0.013 & $(0.008)$ & 0.121 & 0.012 & $(0.008)$ & 0.131 & -0.008 & $(0.007)$ \\
\hline Physical science & 0.016 & -0.001 & $(0.001)$ & 0.017 & 0.000 & $(0.001)$ & 0.016 & -0.001 & $(0.001)$ \\
\hline Social science & 0.151 & $-0.012^{* *}$ & $(0.006)$ & 0.175 & $0.010^{*}$ & $(0.005)$ & 0.146 & -0.002 & $(0.006)$ \\
\hline Vocational technical & 0.014 & -0.001 & $(0.001)$ & 0.014 & -0.002 & $(0.002)$ & 0.011 & -0.003 & $(0.002)$ \\
\hline Average earnings & 76,453 & -214 & (311) & 75,291 & -480 & (359) & 74,486 & 70 & $(231)$ \\
\hline
\end{tabular}

Notes: All specifications also include year fixed effects, college fixed effects, a dummy for 0 to 2 years post adoption of differential (not reported), and are restricted to 4 years before and after the adoption of a price differential for each school. Robust standard errors clustered by school in parentheses. ${ }^{* * *} p<0.01,{ }^{* *} p<0.05,{ }^{*} p<0.1$. All specifications include 142 schools, though the number of schools that adopted a differential tuition policy varies between fields. Model is estimated using OLS. Outcome mean is for colleges that eventually adopted tuition differentials in the pre-differential period. Average earnings is computed for each institution and year using the 2009 and 2010 ACS to compute mean annual earnings for each undergraduate major nationally and then averaging across all majors using an institution's share of degrees granted in each major in each year as weights. 
Figure 1. Distribution of Treatment Effects at Individual Universities
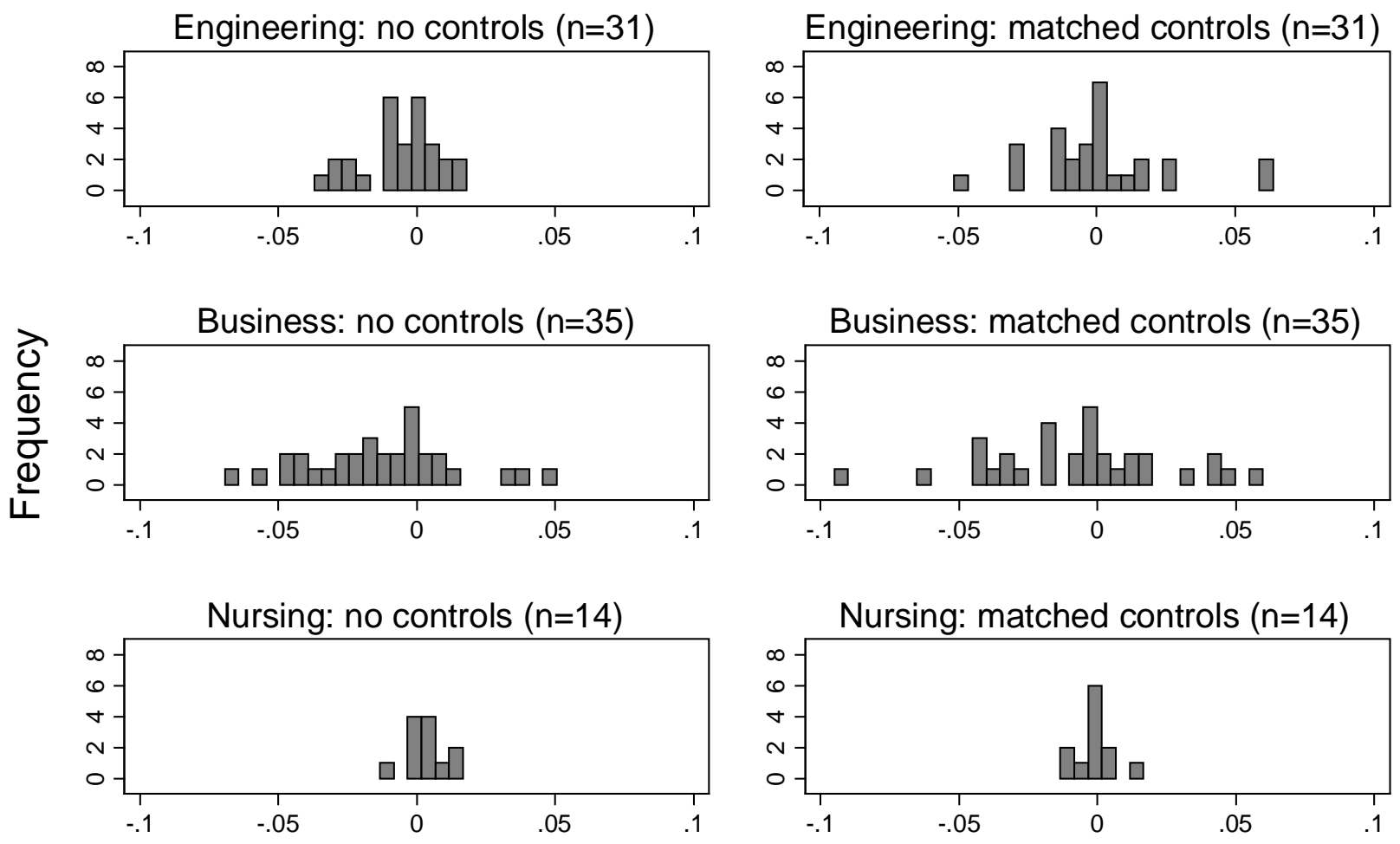

Change in share of All Degrees Following Differential Adoption

Left column plots the distribution of changes in major share of degrees granted following the introduction of differential tuition at each school. Right column plots distribution of school-specific estimates from regression with one treatment school matched with control schools in same Barrons category and census region. 
Figure 2. Event-study Estimates of Effect of Differential Pricing on Major Share
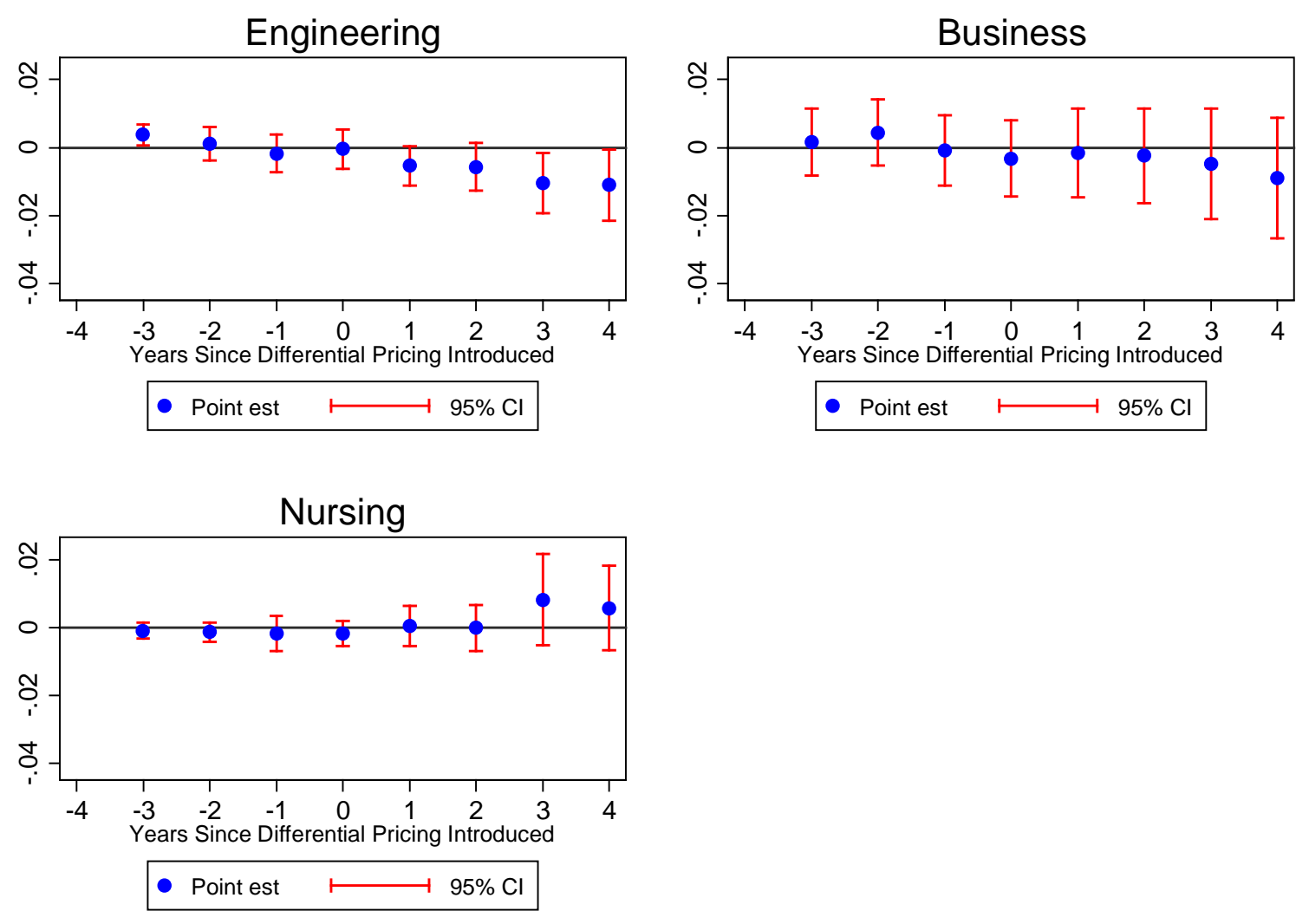

- Point est $\longmapsto 95 \% \mathrm{Cl}$

Notes: Graphs plot the point estimates from the event study model in equation (2) using the restricted (+/- 4 year window) sample. Institution sample includes 142 institutions with known adoption dates for differential pricing. Dependent variable is the share of degrees awarded in the specified field. 
Figure A-1. School-Specific Estimates by Differential Pricing Amount
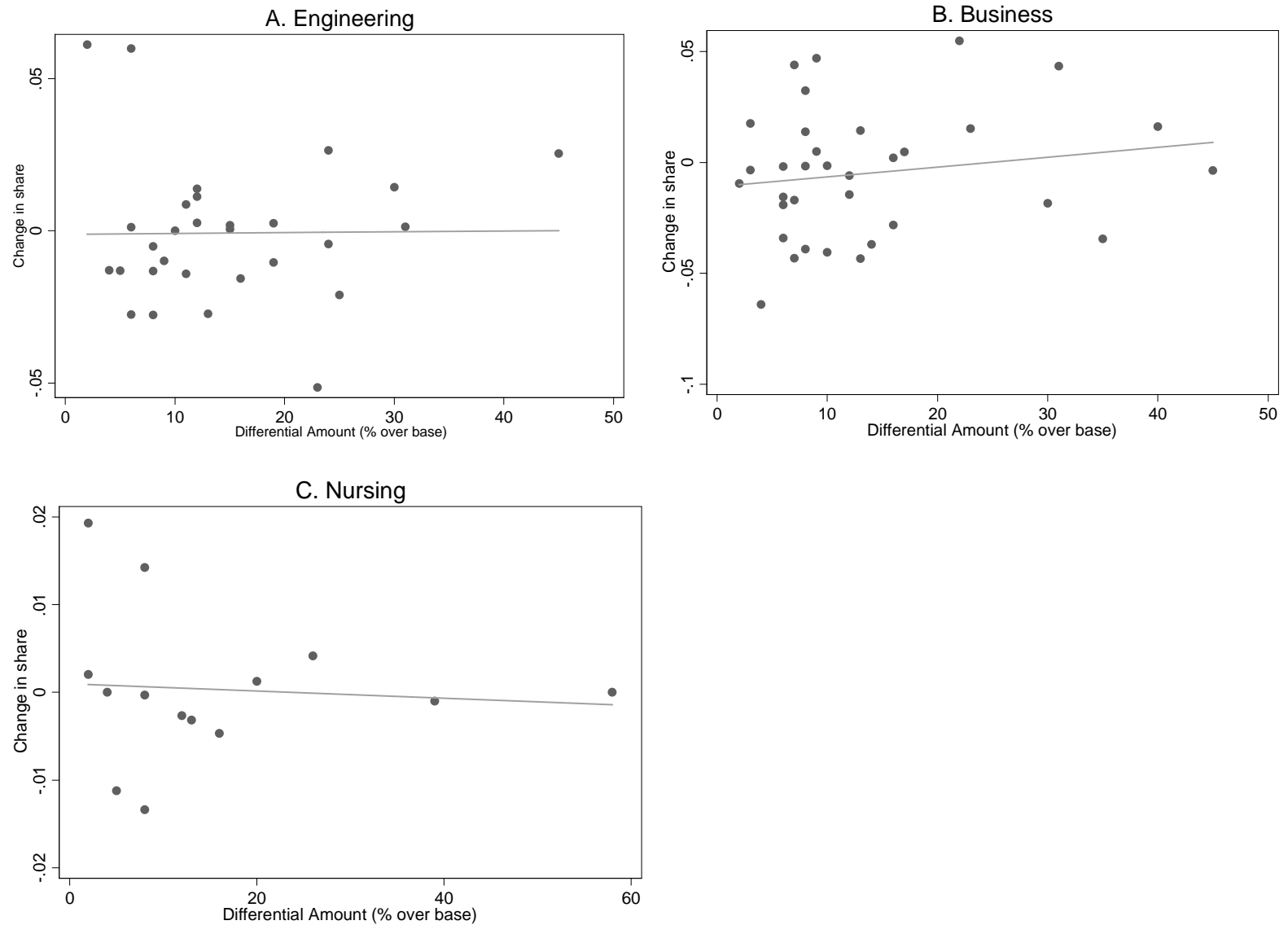

Notes: Each point corresponds to the treatment effect and amount of the price differential (in percent terms over base tuition) for a specific institution that adopted differential pricing for the specified field. Point estimates are from school-specific difference-in-difference estimates with one treatment school matched to control schools in the same Barrons selectivity category and census division. Fitted line is from a simple linear regression. Institution sample includes 142 institutions with known adoption dates for differential pricing. Dependent variable is the share of degrees awarded in the specified field. 